\title{
Isosorbide-based cholinesterase inhibitors; replacement of 5-ester groups leading to increased stability
}

\author{
Gerald P. Dillon ${ }^{\mathrm{a}}$, Joanne M. Gaynor ${ }^{\mathrm{b}}$, Denise Khan ${ }^{\mathrm{a}}$, Ciaran G. Carolan ${ }^{\mathrm{a}}$, Sheila A. Ryder ${ }^{\mathrm{a}}$, Juan F. Marquez $^{\mathrm{a}}$, Sean Reidy $^{\mathrm{b}}$, \\ John F. Gilmer ${ }^{\mathrm{a}}$, \\ ${ }^{\text {a }}$ School of Pharmacy and Pharmaceutical Sciences, Trinity College Dublin, Dublin 2, Ireland \\ ${ }^{\mathrm{b}}$ School of Science, Athlone Institute of Technology, Athlone, Westmeath, Ireland \\ E-mail: gilmerjf@tcd.ie (John F. Gilmer)
}

NOTICE: this is the author's version of a work that was accepted for publication in Bioorganic \& Medicinal Chemistry following peer review. Changes resulting from the publishing process, such as peer review, editing, corrections, structural formatting, and other quality control mechanisms may not be reflected in this document. Changes may have been made to this work since it was submitted for publication. A definitive version was subsequently published in Bioorganic \& Medicinal Chemistry, [Vol. 18, Issue 3 (Feb 2010)], DOI: 10.1016/j.bmc.2009.12.052.

Direct links to the definitive publisher-authenticated version [Dillon GP, Gaynor JM, Khan D, Carolan CG, Ryder SA, Marquez JF, Reidy S, Gilmer JF. Isosorbide-based cholinesterase inhibitors; replacement of 5-ester groups leading to increased stability. Bioorg Med Chem. 2010 Feb; 18(3):1045-53]:

http://www.sciencedirect.com/science/article/pii/S0968089609011444

http://dx.doi.org/10.1016/j.bmc.2009.12.052

\section{Abstract}

Isosorbide-2-carbamate-5-esters are highly potent and selective butyrylcholinesterase inhibitors with potential utility in the treatment of Alzheimer's Disease (AD). They are stable in human plasma but in mouse plasma they undergo hydrolysis at the 5-ester group potentially attenuating in vivo potency. In this paper we explore the role of the 5-position in modulating potency. The focus of the study was to increase metabolic stability while preserving potency and selectivity. Dicarbamates and 5-keto derivatives were markedly less potent than the ester class. The 2-benzylcarbamate-5-benzyl ether was found to be potent $\left(\mathrm{IC}_{50} 52 \mathrm{nM}\right)$ and stable in the presence of mouse plasma and liver homogenate. The compound produces sustained moderate inhibition of mouse butyrylcholinesterase at $1 \mathrm{mg} / \mathrm{kg}$, IP.

\section{Keywords Butyrylcholinesterase inhibitor • Selectivity • Metabolic stability ${ }^{*}$}

\section{Introduction}

The cholinesterases are well established targets now for drugs used to treat glaucoma, myasthenia gravis and Alzheimer's Disease $(A D) .{ }^{1-3}$ Cholinesterase inhibitors also find application in chemoprotection from organophosphate poisoning. ${ }^{4}$ There are two types of cholinestesterase - AChE (3.1.1.7) and BuChE (3.1.1.8). Greatest attention has been paid to AChE due to its classical actions in regulating synaptic acetylcholine and because of less clearly defined, non-enzymatic or non-classical actions. The cholinesterase inhibition strategy in AD treatment arises from the recognition that the cognitive deficits arising in the disease correlate with diminished cholinergic neurotransmission. By inhibiting AChE the functional pool of AChE in the cholinergic neurons is augmented.

BuChE has generally received less attention mainly because its biological function is not as clearly defined as is that of AChE and although it is more ubiquitous than AChE its distribution in the CNS has not traditionally been recognized as consistent with an important role in neurotransmission, at least in the healthy brain. The several drugs on the market for $A D$ are therefore more or less selective for AChE. There has been a surge in interest in BuChE as a potential target for AD treatment in recent years due to a number of factors: (i) the nullizygote (AChE -/-) mouse while having a clear phenotype appears to have normal CNS function, indicating at least a compensatory role for BuChE in the CNS ${ }^{5}$; (ii) while synaptic AChE levels decrease markedly in $A D$ progression, there is a corresponding increase in BuChE activity ${ }^{6}$; (iii) post mortem tissue analysis on $A D$ patients shows a high level of BuChE in the hallmark lesions of $A D .^{7}$ In rats, the selective BuChE inhibitor cymserine causes elevation of acetylcholine and augments long term potentiation and learning. ${ }^{8}$

Abbreviations: AChE, acetylcholinesterase; ATCI, acetylthiocholine iodide; BTCI, butyrylthiocholine iodide; BuChE, butyrylcholinesterase; DCC, dicyclohexylcarbodiimide; DTNB, 5,5'-dithiobis-(2-nitrobenzoic acid); huBuChE, human butyrylcholinesterase; ISMN, isosorbide-5mononitrate; ISMNA, isosorbide mononitrate aspirinate; MAO, monoamine oxidase; SAR, structure-activity relationship, TBAF, tetrabutylammonium fluoride; TBDMS, tertbutyldimethylsilyl; TLC, thin layer chromatography; TMS, tetramethylsilane. 
Isosorbide-2-carbamate-5-esters (Fig. 1) are nanomolar BuChE inhibitors with very high selectivity over AChE (up 60,000fold). ${ }^{9}$ Although they possess a 5-ester group, they are stable in human plasma because inhibitory interactions with BuChE (arising as a result of enzymatic interactions with the 2-carbamate functionality) are preferred over substrate (5-ester) interactions. However, during in vivo experiments in a mouse model of memory and learning it became apparent that compound 1a $\left(R^{\prime}=P h\right)$ was undergoing hydrolysis in plasma and liver tissue at the 5-ester position generating the less potent isosorbide-2-carbamate and benzoic acid. ${ }^{10}$ Mouse plasma possesses carboxylesterases which are absent in human plasma, and the undesirable degradation of the esters could be attributed to these enzymes. In this paper we investigate the relationship between 5-substituent and esterase inhibition in order to better understand the SAR for the class and to find a more stable but potent and selective BuChE inhibitor that could be used to probe the role of the enzyme in the mouse.

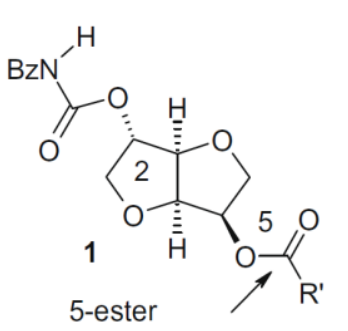

vulnerable to murine carboxylesterases

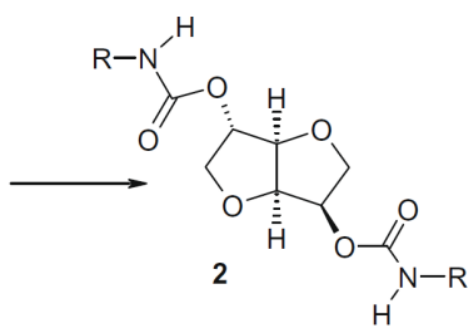

2,5-dicarbamates

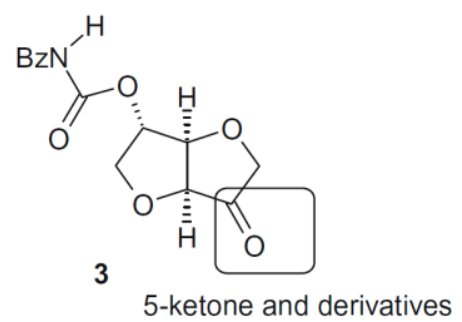

5-ketone and derivatives

Figure 1. General strategy for increasing metabolic stability towards rodent carboxylesterases.

\section{Results and discussion}

\subsection{Chemistry}

Dicarbamates (2a-2f) were prepared by heating isosorbide (4) in dry pyridine in the presence of an excess of the appropriate isocyanate for $1-2 \mathrm{~h}$ at $100^{\circ} \mathrm{C}$ (Scheme 1$)$. The excess isocyanate was removed by adding methanol and the mixture poured into ice-water. The target dicarbamates precipitated over a couple of hours.

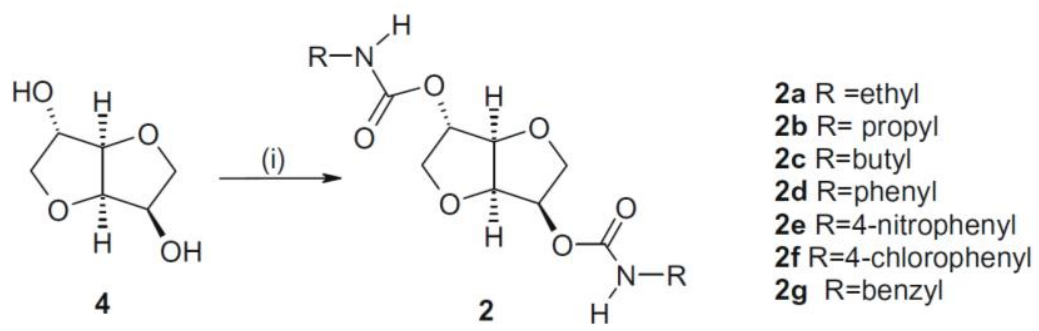

Scheme 1. Preparation of the dicarbamates $2 a-g$ : (i) isocyanate, pyr, $100{ }^{\circ} \mathrm{C}, 1-2 \mathrm{~h}, 50-70 \%$.

The clinically used isosorbide mononitrate (ISMN) $\mathbf{5}$ is a convenient material for exploring isosorbide chemistry because the difficult step of introducing regioselectivity has already been achieved and the nitrate is easily removed by reduction after elaboration of the 2-position. As reported previously isosorbide benzyl carbamates have optimal potency and selectivity for BuChE. Therefore the 2-position of ISMN (5) was carbamylated using benzyl isocyanate. Selective removal of the 5-nitrate was effected using $\mathrm{Pd} / \mathrm{C}$ over $\mathrm{H}_{2}$ and the triflate ester introduced using triflic anhydride. The alkene 7 was obtained by elimination of the intermediate triflate using DBU (Scheme 2). The 5,6-ene was distinguished from the potential isomeric 4,5-ene compound by the collapse of the 6-methylene group in the proton NMR and by the presence of signals for the 5and 6-methine hydrogens.

The 5-ketone $\mathbf{3}$ was synthesised in order to determine the effect of flattening the isosorbide ring on ligand-BuChE interactions, and because the ketone is not susceptible to esterase-mediated metabolism. The ketone (3) was produced in good yield from isosorbide-2-benzylcarbamate-5-OH (6) using PCC in DCM with silica gel catalysis (Scheme 3). A number of classical or established ketone transformations were then attempted (Scheme 3). The 5-oxime (8) was generated by stirring with hydroxylamine hydrochloride in aqueous solution at high temperature. The oxime benzoate ester (9) was produced following acylation of $\mathbf{8}$ with benzoyl chloride and DMAP catalysis. Baeyer Villiger oxidation was accomplished by stirring $\mathbf{3}$ with $m C P B A$ in DCM generating lactone 10. Rearrangements of isosorbide-based ketones proceed with the expected migration of the more substituted alpha 4-carbon. The analogous Beckmann rearrangement was also performed on $\mathbf{3}$ using $\mathrm{N}$-methylhydroxylamine in the presence of sodium acetate generating lactam $\mathbf{1 1}$ (the intermediate methyl ketoxime arising carried through without purification). Wittig reaction on $\mathbf{3}$ using the commercially available ylide, carbethyloxymethylene triphenylphosphorane yielded the alkenyl ester (12). The beta-amide 16 (Scheme 4) was accessed via a different strategy. 

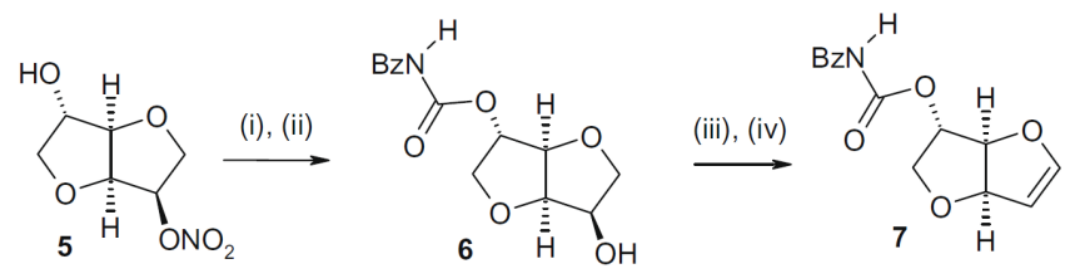

Scheme 2. The preparation of alkene compound 7. Reagents and conditions: (i) benzyl isocyanate, $E t_{3} N, D M A P, D C M, 40{ }^{\circ} \mathrm{C}, 2 \mathrm{~h}$; (ii) $P d / C$, $H_{2}$, EtOAc, $12 \mathrm{~h}$, rt; (iii) $\mathrm{Tf}_{2} \mathrm{O}, \mathrm{Et} \mathrm{t}_{3} \mathrm{~N}, \mathrm{DCM}$; (iv) DBU, Tol, $6 \mathrm{~h}, \mathrm{rt}, 16 \%$.
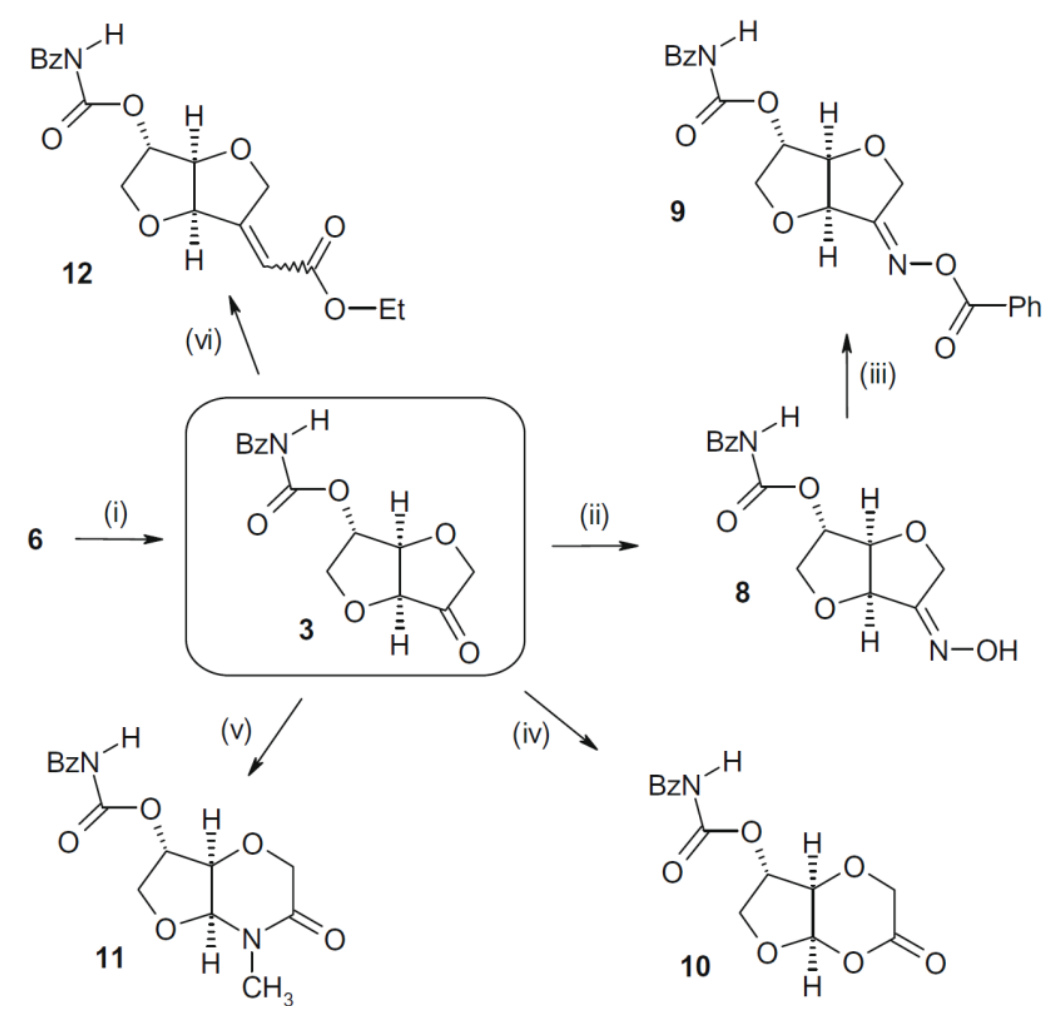

Scheme 3. The preparation of ketone derivatives. Reagents and conditions: (i) $P C C, D C M, r t, 8 h$; (ii) $\mathrm{NH}_{2} \mathrm{OH} . \mathrm{HCl}, \mathrm{MeOH} / \mathrm{H}_{2} \mathrm{O}$ (2:1), $4 h$, $85^{\circ} \mathrm{C}$; (iii) PhC(O)Cl, Et $t_{3} \mathrm{~N}, \mathrm{DMAP}, \mathrm{DCM}, 4 \mathrm{~h}, \mathrm{rt}$, 78\%; (iv) $\mathrm{mCPBA}, \mathrm{NaHCO}_{3}, \mathrm{DCM}, 12 \mathrm{~h}, 0{ }^{\circ} \mathrm{C}, 39 \%$; (v) MeNHOH, NaOAC, EtOH, N $2,4 \mathrm{~h}, \mathrm{rt}$ then $\mathrm{TsCl}, \mathrm{Pyr}, 6 \mathrm{~h}, \mathrm{O}^{\circ} \mathrm{C}, 35 \%$; (vi) $\mathrm{Ph}_{3} \mathrm{PCHC}(\mathrm{O}) \mathrm{OEt}, \mathrm{THF}, 0{ }^{\circ} \mathrm{C}, 6 \mathrm{~h}, 45 \%$.

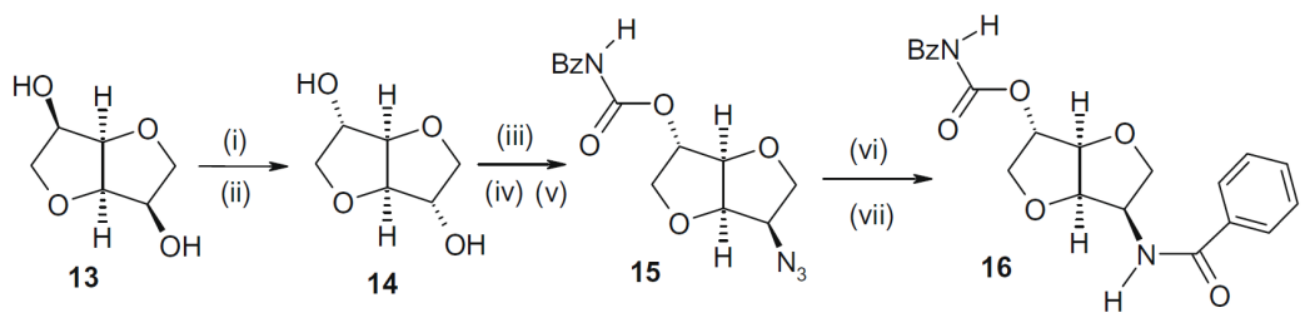

Scheme 4. The preparation of 5-amide 16. Reagents and conditions: (i) 4 equiv TsCl, pyr, rt; (ii) $\mathrm{NaOAc}, \mathrm{MeOH}$, then $\mathrm{NaOH}, \mathrm{H}_{2} \mathrm{O}$; (iii) 1 equiv TsCl, Pyr, $24 \mathrm{~h}, 0{ }^{\circ} \mathrm{C}, 59 \%$; (iv) $\mathrm{NaN}_{3}, \mathrm{DMSO}, 125^{\circ} \mathrm{C}, 24 \mathrm{~h}, 64 \%$; (v) benzyl isocyanate, $E t_{3} \mathrm{~N}, \mathrm{DMAP}, \mathrm{DCM}, 40{ }^{\circ} \mathrm{C}, 2 \mathrm{~h}$; (vi) Pd/C, $\mathrm{H}_{2}$, EtOAc/MeOH $24 \mathrm{~h}, \mathrm{rt}$; (vii) $\mathrm{PhC}(\mathrm{O}) \mathrm{Cl}, \mathrm{Et} \mathrm{t}_{3} \mathrm{~N}, \mathrm{DMAP}, \mathrm{DCM}, 4 \mathrm{~h}, \mathrm{rt}, 20 \%$ from (14).

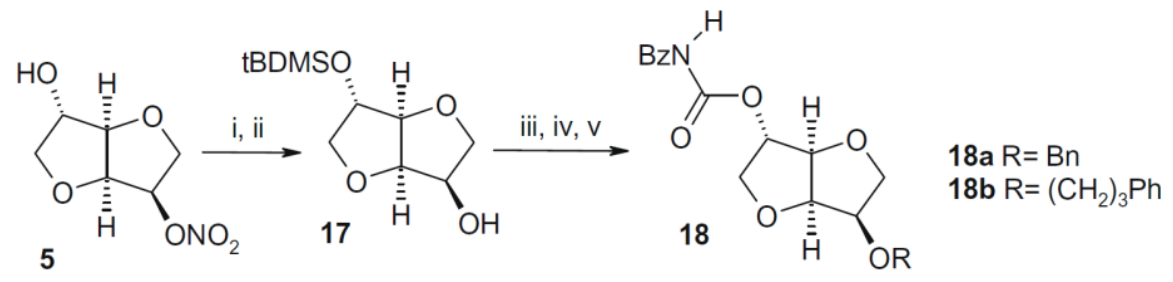

Scheme 5. The preparation of 5-ethers. Reagents and conditions: (i) ${ }^{t} B D M S C l$, imidazole, DMAP, DCM, 28 , rt; (ii) $\mathrm{H}_{2}, \mathrm{Pd} / \mathrm{C}, \mathrm{MeOH} / \mathrm{EtOAC}$, $24 \mathrm{~h}, \mathrm{rt}$; (iii) $\mathrm{NaH}, \mathrm{RBr}, 24 \mathrm{~h}, \mathrm{THF}, \mathrm{rt}, 56 \%$; (iv) TBAF, THF, rt, $15 \mathrm{~min}$; (v) benzyl isocyanate, pyr, $105^{\circ} \mathrm{C}, 2 \mathrm{~h}$. 
Isoiodide (14) was generated from the commercially available isomannide (13) by bistosylation followed by $\mathrm{SN}_{2}$ substitution with sodium acetate and hydrolysis. Monotosylation of isoiodide $\mathbf{1 4}$ was accomplished by treating the diol with a single equivalent of tosyl chloride at low temperature. The monotosylate was isolated by chromatography and treated with sodium azide to afford the 5-azide, isosorbide-5-deoxyazide (15). The azide, which was easier to handle than the corresponding amine, was carbamylated at the 2-position using benzyl isocyanate and a tertiary base. The 5-azido group was then reduced to beta-amine and acylated with benzoyl chloride to afford the beta-amide 16 (Scheme 5).

Lastly, a number of 5-ether compounds were prepared as the ether functionality is resistant to esterase-induced hydrolysis. Treatment of 6 with benzyl or phenylethyl bromide yielded insufficient target ether because of concomitant alkylation of the 2-carbamate nitrogen. Therefore, ISMN was TBDMS protected, the 5-nitrate removed by reduction yielding 17 and the $5-\mathrm{OH}$ group alkylated. The TBDMS protection was then removed and the 2-position converted to benzylcarbamate resulting in the benzyl and phenylpropyl ethers $\mathbf{1 8 a}$ and $\mathbf{1 8 b}$.

\subsection{Cholinesterase inhibition}

Cholinesterase inhibition was determined using the Ellman method ${ }^{11}$ with human plasma BuChE or electric eel AChE with butyryl- or acetyl-thiocholine as substrates as appropriate (Table 1). The test compounds were incubated in the presence of enzyme for $30 \mathrm{~min}$ at $100 \mu \mathrm{M}$ prior to addition of substrate. The inhibition experiments were repeated at successively lower concentrations to determine the $30 \mathrm{~min} I C_{50}$ only where there was significant inhibition (>90\%) at $100 \mu \mathrm{M}$. This corresponded to the solubility limit for the compounds in the assay medium. The seven dicarbamates (2) were tested first as these were the easiest to make. The diethyl compound $2 \mathrm{a}$ was a moderately potent $\mathrm{AChE}$ inhibitor $\left(\mathrm{IC}_{50}, 6.5 \mu \mathrm{M}\right)$ whereas the dibutyl compound $\mathbf{2 c}$ was a moderately potent and selective BuChE inhibitor $\left(\mathrm{IC}_{50}, 1.2 \mu \mathrm{M}\right)$. The most potent BuChE inhibitor in the series of di-carbamates tested was the di-benzyl carbamate $\mathbf{2 g}\left(\mathrm{IC}_{50}, 0.4 \mu \mathrm{M}\right)$. Amongst AChE inhibitors, the di-4-nitrophenyl carbamate $\mathbf{2 e}$ was most potent $\left(\mathrm{IC}_{50}, 5.4 \mu \mathrm{M}\right)$. Interestingly, the di-4-chlorophenyl carbamate $\mathbf{2 f}$ failed to inhibit either cholinesterase enzyme to any significant extent.

Table 1. Inhibition data for BuChE and AChE using human plasma BuChE or erythrocyte $A C h E\left(n=6, \pm s d, I C_{50}\right.$ or mean \% inhibition).

\begin{tabular}{llll}
\hline & BuChE & AChE & Selectivity $^{\text {a }}$ \\
\cline { 2 - 3 } & \% Inhibition at $\mathbf{1 0 0 ~} \boldsymbol{\mu M}$ or $\mathbf{I C}_{\mathbf{5 0}}(\boldsymbol{\mu M})$ & \\
\hline $\mathbf{2 a}$ & $55.12 \%$ & $6.5 \pm 1.1$ & AChE 15.4 \\
$\mathbf{2 b}$ & $10.4 \pm 1.2$ & $28 \%$ & BuChE 9.6 \\
$\mathbf{2 c}$ & $1.22 \pm 0.28$ & $13 \%$ & BuChE 81 \\
$\mathbf{2 d}$ & $20.6 \%$ & $77 \%$ & - \\
$\mathbf{2 e}$ & $17.4 \%$ & $5.4 \pm 1.4$ & AChE 18.5 \\
$\mathbf{2 f}$ & $7.96 \%$ & - & - \\
$\mathbf{2 g}$ & $0.4 \pm 0.06$ & $77 \%$ & BuChE 250 \\
$\mathbf{3}$ & $46 \%$ & $10 \%$ & - \\
$\mathbf{7}$ & $10.25 \pm 0.8$ & $9.8 \%$ & BuChE 9.7 \\
$\mathbf{8}$ & $40 \%$ & $83 \%$ & - \\
$\mathbf{9}$ & $64.8 \%$ & $9 \%$ & - \\
$\mathbf{1 0}$ & $56 \%$ & $10 \%$ & - \\
$\mathbf{1 1}$ & $63 \%$ & $6.5 \%$ & - \\
$\mathbf{1 2}$ & $4.8 \pm 0.9$ & $4.9 \%$ & BuChE 21 \\
$\mathbf{1 5}$ & $50.4 \%$ & $5 \%$ & - \\
$\mathbf{1 6}$ & $88 \%$ & $46 \%$ & - \\
$\mathbf{1 8 a}$ & $0.052 \pm 0.007$ & $55 \%$ & BuChE 1923 \\
$\mathbf{1 8 b}$ & $0.201 \pm 0.043$ & $51 \%$ & BuChE 497 \\
\hline
\end{tabular}

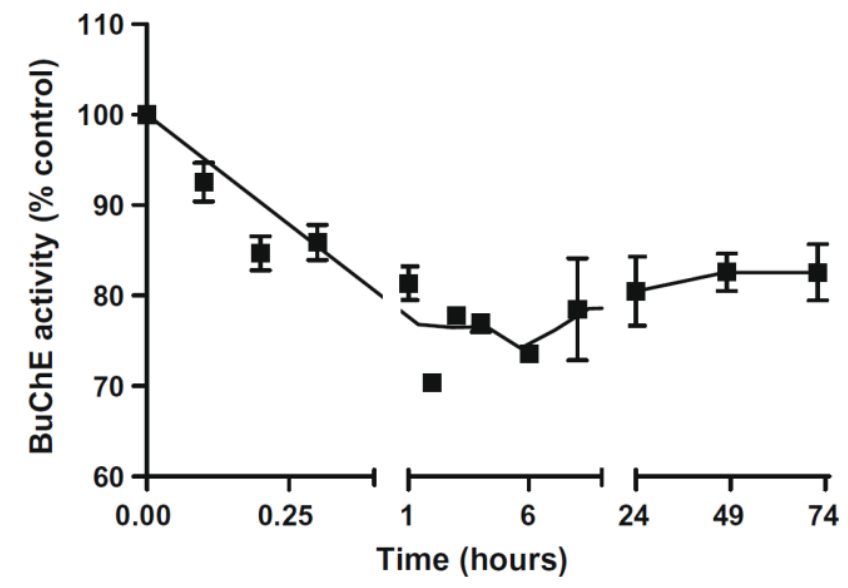

Figure 2. The effect of a single ip dose of compound 18 a at $1 \mathrm{mg} / \mathrm{kg}$ on mouse plasma BuChE measured ex vivo (9 animals with $n=3$ per time point).

${ }^{a}$ Calculated from the ratio of BuChE or $A C h E I C_{50}$, or using a value of $100 \mu \mathrm{M}$ where the $I C_{50}$ value was not determined.

The 5-ketone, 5-oxime and 5-oxime benzoate ester derivatives of isosorbide were all poor inhibitors of both cholinesterase enzymes. This suggested that flattening of the functionality at the 5 position so that it was planar with the attached ring of isosorbide was detrimental to inhibition in both instances. In all other instances tested and described previously as well as in this article, the 5-group of active inhibitors was always positioned endo to the V-shaped isosorbide ring, and this result confirms that this orientation is important for activity. It was interesting that compound $\mathbf{1 2}$, however, which included an ethyl ester group attached to a planar alkene functionality - which itself would be planar with the isosorbide ring in a similar manner to the ketone and oxime compounds - was a moderately potent BuChE inhibitor (IC $50,4.8 \mu \mathrm{M})$. For this particular compound, the replacement of the nitrogen atom of the oxime functionality with an oxygen means that the 
remainder of the functionality is at an angle to the isosorbide core, and this may allow for more avid binding as is implied from the potency of inhibition; this is discussed further below.

Modification of the isosorbide template by incorporation of lactam and lactone rings in place of one of the five-membered rings (compounds $\mathbf{1 0}$ and 11, respectively) also negatively affected inhibitor potency. The lactam structure inhibited BuChE by just $63 \%$ at $100 \mu \mathrm{M}$ and the lactone by $56 \%$ at the same concentration; inhibition of AChE was even less apparent. Similarly, the 5-azide derivative (15) was a relatively poor inhibitor of the cholinesterases. The $\beta$-amide structure (16) showed more promise, inhibiting BuChE by $88 \%$ at $100 \mu \mathrm{M}$.

The most potent inhibitors were the ether compounds. The addition of a phenylpropyl ether moiety at the 5-position of isosorbide (18b) resulted in a potent BuChE inhibitor with an $\mathrm{IC}_{50}$ of $200 \mathrm{nM}$, while the benzyl ether derivative (18a) had an $\mathrm{IC}_{50}$ of $50 \mathrm{nM}$. This compound could be ranked alongside some of the most potent ester derivatives of isosorbide described previously, but had the added advantage that it was not susceptible to esterase-mediated hydrolysis in vivo.

\subsection{Mouse cholinesterase inhibition}

To confirm that the potent ether compound (18a) was stable in mouse plasma and could effect BuChE inhibition in the mouse model, the compound was administered to mice $(n=3)$ at $1 \mathrm{mg} / \mathrm{kg} \mathrm{IP}$. As shown in Figure 2 , administration was associated with significant inhibition of peripheral plasma BuChE activity. More crucially, this inhibition was apparent for more than $72 \mathrm{~h}$, indicating that the compound was stable and not subject to carboxylesterase-mediated degradation as was the case for the ester compounds described previously. This compound will be useful if the mouse model is to be used for examining the consequences of BuChE inhibition in vivo.

\subsection{Discussion}

At first glance the SAR of the isosorbide-based carbamates of interest in this article appears complex. However, on close inspection, a number of patterns emerge.

Amongst the series as a whole, the compounds tend to have a preference for BuChE inhibition over AChE inhibition - a pattern that is in keeping with all isosorbide-based carbamate inhibitors described to date. ${ }^{9,12}$ The di-carbamate compounds are the only ones that show significant inhibition of AChE amongst those tested herein, with both the di-ethyl and di-4nitrophenyl carbamates being most potent. This result is not entirely surprising when the SAR of the compounds described previously is considered. Aside from the di-carbamates, all other compounds described in this article have a benzyl carbamate moiety at the 2-position of isosorbide. Previous work has shown that the presence of a benzyl carbamate at this position is optimal for BuChE inhibition, and in fact increases selectivity over AChE inhibition to a reasonable extent, helping to explain this first finding.

Modelling studies described previously help to explain this. The cholinesterase enzymes are members of the $\alpha / \beta$-hydrolase fold family of enzymes, and have their active sites located at the base of a gorge some $20 \AA$ deep. ${ }^{13,14} \mathrm{~A}$ number of important residues and subsites that form this gorge have been described. Our own work indicates that the functionality at the 2-position of isosorbide extends into the acyl pocket of the cholinesterase enzymes upon productive binding (as required for carbamylation and subsequent prolonged inhibition of the enzyme). The pocket in BuChE, lined by a leucine and valine residue (residues Leu286 and Val288 in huBuChE) is larger than in AChE, in which the acyl pocket is occluded by the presence of two large phenylalanine residues (Phe288 and Phe290, numbering according to Torpedo californica enzyme). This means that larger groups such as the benzyl carbamate - as well as the butyl, and to a lesser extent, propyl carbamates now described occupy the BuChE pocket well, whereby they are too large to be accommodated by AChE. Thus, AChE has a tendency to be more selective for compounds with a smaller functionality at the 2-position, and this is apparent amongst our compounds where the di-ethyl and di-phenyl carbamates are the most potent inhibitors of the enzyme.

If we focus on BuChE inhibition, it is clear from the results that the isosorbide moiety itself is also important for activity, as is the presence of a suitable functionality at the 5-position of the sugar. The lactam and lactone compounds were relatively poor inhibitors, indicating that the fused five-membered ring structure of isosorbide is probably more optimal. The poor inhibition apparent for these compounds may also be due to the fact that they both have carbonyl groups attached. Amongst the series of compounds tested, all of those with flat ketone or oxime groups attached at the 5-position were quite poor cholinesterase inhibitors. Once again, modelling described previously could hint as to why this might be the case - the moiety at the 5-position when the group is endo to the V-shaped isosorbide ring extends upwards towards the gorge entrance, stacking vertically against the cation- $\pi$ site (Trp82 in huBuChE) and extending towards the peripheral site residues. Extension of a group in a different direction - that is, in an exo orientation or indeed planar to the isosorbide ring - means that groups are directed towards the gorge wall, where there is little space for accommodation of functionalities of any reasonable size. Amongst compounds without side-chains attached directly to isosorbide in an endo orientation, only compound 12 was especially potent. However, it had a freely-rotatable ethyl-ester functionality immediately attached that could orientate itself in such a way to extend upwards towards the gorge entrance, interacting favorably with residues in the mid-gorge and upper-gorge regions. 
The ether compounds were the most potent BuChE inhibitors synthesized in this study. It is hardly surprising that the benzyl ether compound, 18a, was the most potent, as it closely resembles the benzyl ester compounds that were found to be optimal for BuChE inhibition in previous studies, ${ }^{9}$ differing only in its lack of an ester carbonyl group. Clearly, it can orientate itself in a similar manner in the BuChE active site and form many of the same interactions, thus favoring carbamylation of the catalytic serine. With an $\mathrm{IC}_{50}$ of $4 \mathrm{nM}$, isosorbide 2-benzyl carbamate 5-benzoate is a more potent inhibitor of BuChE; the difference may be attributed in large part to the stacking interactions that can form between the double bond of the carbonyl group and the indole ring of Trp82. However, the loss of affinity is warranted for our purposes as the ether compound is stable in the presence of carboxylesterase enzymes in mouse plasma.

\section{Conclusions}

Some potent isosorbide 2-carbamate 5-ester inhibitors of BuChE are degraded rapidly by carboxylesterase enzymes found in mouse plasma, meaning that their use as agents to probe the effects of BuChE inhibition in the important mouse model is inappropriate. We have created a series of compounds in which the labile 5-ester group has been modified and tested their potency as cholinesterase inhibitors. It was found that isosorbide 2-carbamate 5-ether compounds are nanomolar inhibitors of BuChE with negligible effects on AChE. One of these 18a is stable in mouse plasma and its administration can effect enzyme inhibition for sustained periods of time. We expect that this compound will be useful for probing BuChE roles and effects in mice going forward.

\section{Experimental}

\subsection{Chemistry}

Uncorrected melting points were obtained using a Stuart ${ }^{\circledR}$ melting point SMP11 melting point apparatus. Spectra were obtained using a Perkin Elmer 205 FT Infrared Paragon 1000 spectrometer. Band positions are given in $\mathrm{cm}^{-1}$. Solid samples were obtained by $\mathrm{KBr}$ disk; oils were analyzed as neat films on $\mathrm{NaCl}$ plates. ${ }^{1} \mathrm{H}$ and ${ }^{13} \mathrm{C}$ spectra were recorded at $27{ }^{\circ} \mathrm{C}$ on a Bruker Advance II $600 \mathrm{MHz}$ spectrometer $\left(600.13 \mathrm{MHz}{ }^{1} \mathrm{H}, 150.91 \mathrm{MHz}{ }^{13} \mathrm{C}\right)$ and Bruker DPX $400 \mathrm{MHz}$ FT NMR spectrometer (400.13 M Hz ${ }^{1} \mathrm{H}, 100.16 \mathrm{MHz}^{13} \mathrm{C}$ ), in either $\mathrm{CDCl}_{3}$ or DMSO- $d_{6}$, (tetramethylsilane as internal standard). High resolution mass spectrometry (HRMS) was performed on a Micromass mass spectrophotometer (El mode) at the Department of Chemistry, Trinity College. HPLC was performed on a reverse phase $250 \mathrm{~mm} \times 4.6 \mathrm{~mm}$ Waters Spherisorb ODS-2, $5 \mu \mathrm{m}$ column using a Waters Alliance 2695 chromatograph equipped with an autosampler, column oven and dual wavelength detector. The flow rate was $1 \mathrm{~mL} / \mathrm{min}$ with a mobile phase consisting of $40 \%$ phosphate buffer $\mathrm{pH} 2.5$ and $60 \%$ acetonitrile at time 0 and grading to $85 \%$ acetonitrile at $4 \mathrm{~min}$. Injection volume was $20 \mu \mathrm{L}$, and areas determined at $254 \mathrm{~nm}$. The isocratic HPLC method was aqueous phosphate buffer solution pH $2.540 \%$ and acetonitrile $60 \%$. Flow rate was $1 \mathrm{~mL} / \mathrm{min}$. Flash chromatography was performed on Merck Kieselgel 60 particle size $0.040-0.063 \mathrm{~mm}$. TLC was performed on silica gel Merck F-254 plates. Compounds were visually detected by absorbance at $254 \mathrm{~nm}$ and/or vanillin staining.

\subsubsection{Isosorbide-di-(ethylcarbamate) (2a)}

General procedure for dicarbamates (2): Isosorbide (0.7304 g, $5 \mathrm{mmol}$ ) was dissolved in dry pyridine (5 $\mathrm{mL})$, the appropriate isocyanate $(15 \mathrm{mmol})$ was added and the mixture heated at $100{ }^{\circ} \mathrm{C}$ for $1.5 \mathrm{~h}$. The mixture was cooled and $\mathrm{methanol}(7 \mathrm{~mL})$ added to remove excess isocyanate. It was heated for $10 \mathrm{~min}$ at $100{ }^{\circ} \mathrm{C}$, cooled to room temperature, poured into ice-water, precipitate filtered and recrystallised twice from hot methanol to yield a white crystalline product $(18 \%): \mathrm{mp} 169.9^{\circ} \mathrm{C}$. IR $\mathrm{R}_{v m a x}$ $(\mathrm{KBr}): 1693(\mathrm{C}=0), 3333\left(2^{\circ} \mathrm{NH}\right) \mathrm{cm}^{-1} .{ }^{1} \mathrm{H}$ NMR $\delta\left(\mathrm{CDCl}_{3}\right): 1.05-1.09\left(\mathrm{~m}, 6 \mathrm{H}, 2 \times \mathrm{CH}_{3}\right), 3.11-3.19\left(\mathrm{~m}, 4 \mathrm{H}, 2 \times \mathrm{CH}_{2}\right), 3.61-3.95$ $\left(2 \mathrm{~m}, 4 \mathrm{H}, \mathrm{IsH}-6, \mathrm{IsH}-6^{\prime}, \mathrm{IsH}-1, \mathrm{IsH}-1^{\prime}\right), 4.42-4.43(\mathrm{~d}, 1 \mathrm{H}, J=4 \mathrm{~Hz}, \mathrm{IsH}-3), 4.68-4.70(\mathrm{t}, 1 \mathrm{H}, J=5.2 \mathrm{~Hz}, \mathrm{IsH}-4),[4.90-4.97(2 \mathrm{~s}, 1 \mathrm{H}$ $\mathrm{N}-\mathrm{H}), 5.02-5.06(\mathrm{~m}, 4 \mathrm{H}, \mathrm{IsH}-2, \mathrm{IsH}-5)] .{ }^{13} \mathrm{C} \mathrm{NMR} \mathrm{ppm}\left(\mathrm{CDCl}_{3}\right): 15.45,15.50\left(\mathrm{CH}_{3}\right), 36.27,36.35\left(\mathrm{CH}_{2}\right), 70.33(\mathrm{IsC}-6), 74.22-$ 74.47 (IsC-1), 77.16-77.80 (IsC-5), 78.65 (IsC-2), 81.38 (IsC-4), 86.23 (IsC-3), 155.51, 155.82 (CO). $\mathrm{C}_{12} \mathrm{H}_{20} \mathrm{~N}_{2} \mathrm{O}_{6}$ requires C, 49.99; H, 6.99; N, 9.7. Found: C, 50.08; H, 7.05; N, 9.46.

\subsubsection{Isosorbide-di-(propylcarbamate) (2b)}

A white crystalline product (28\%): $\mathrm{mp} 137^{\circ} \mathrm{C}$. IR $\mathrm{R}_{\text {vmax }}(\mathrm{KBr}): 1699(\mathrm{C}=0), 3327\left(2^{\circ} \mathrm{NH}\right) \mathrm{cm}^{-1} .{ }^{1} \mathrm{H} \mathrm{NMR} \delta$ (DMSO): $0.8-0.9(\mathrm{t}$, $6 \mathrm{H}), 1.35-1.44(\mathrm{~m}, 4 \mathrm{H}), 2.90-2.95(\mathrm{q}, 4 \mathrm{H}, \mathrm{J}=6.8 \mathrm{~Hz}), 3.61-3.64(\mathrm{~m}, 1 \mathrm{H}), 3.78-3.89(\mathrm{~m}, 3 \mathrm{H}), 4.36-4.44(\mathrm{~d}, 1 \mathrm{H}), 4.66-4.68(\mathrm{t}$, $1 \mathrm{H}), 4.91-4.92(\mathrm{~d}, 1 \mathrm{H}), 4.95-4.99(\mathrm{q}, 1 \mathrm{H}), 7.28-7.31(\mathrm{t}, 1 \mathrm{H}), 7.34-7.36(\mathrm{t}, 1 \mathrm{H}) .{ }^{13} \mathrm{C}$ NMR ppm (DMSO): 11.51, 11.55, 22.90, $22.92,42.34,42.36,70.33,73.18,73.65,77.85,81.12,85.93,155.58,155.81$.

\subsubsection{Isosorbide-di-(buty/carbamate) (2c)}

A white crystalline product $(72 \%)$. IR $\mathrm{R}_{v \max }(\mathrm{KBr}): 1691(\mathrm{C}=0), 3329\left(2^{\circ} \mathrm{NH}\right) \mathrm{cm}^{-1} .{ }^{1} \mathrm{H} \mathrm{NMR} \delta\left(\mathrm{CDCl}_{3}\right): 0.91-0.95(\mathrm{~m}, 6 \mathrm{H}), 1.30-$ 1.1.38 (m, 4H), 1.45-1.53 (m, 4H), 3.16-3.22 (m, 4H), 3.68-3.3.72 (m, 1H), 3.97-4.03 (m, 3H), 4.49-4.51 (d, 1H), 4.75-4.79 $(\mathrm{m}, 2 \mathrm{H}), 4.89(\mathrm{t}, 1 \mathrm{H}), 5.09-5.14(\mathrm{~m}, 2 \mathrm{H}) .{ }^{13} \mathrm{C} \mathrm{NMR} \mathrm{ppm}\left(\mathrm{CDCl}_{3}\right): 13.25,19.41,31.41-31.45,40.32-40.39,69.45,73.45,73.68$, 77.87, 80.56, 85.38, 154.75. $\mathrm{C}_{16} \mathrm{H}_{2} \mathrm{~N}_{2} \mathrm{O}_{6}$ requires $\mathrm{C}, 55.79 ; \mathrm{H}, 8.20 ; \mathrm{N}, 8.14$. Found: $\mathrm{C}, 55.65 ; \mathrm{H}, 8.29 ; \mathrm{N}, 8.11$. 


\subsubsection{Isosorbide-di-phenylcarbamate (2d)}

A white crystalline product (51\%): $\mathrm{mp} 178.8^{\circ} \mathrm{C}, \mathrm{IR}_{\text {max }}(\mathrm{KBr}): 1702(\mathrm{C}=0), 3309\left(2^{\circ} \mathrm{NH}\right) \mathrm{cm}^{-1} .{ }^{1} \mathrm{H}$ NMR $\delta(\mathrm{DMSO}): 3.8-3.9(2 \mathrm{~m}$, $2 \mathrm{H}), 4.0(\mathrm{~m}, 2 \mathrm{H}), 4.5(\mathrm{~d}, 1 \mathrm{H}, J=4.8 \mathrm{~Hz}), 4.8-4.9(\mathrm{t}, 1 \mathrm{H}, J=5.2 \mathrm{~Hz}), 5.1-5.2(\mathrm{~m}, 2 \mathrm{H}), 7.0(\mathrm{~m}, 2 \mathrm{H}), 7.3(\mathrm{t}, 4 \mathrm{H}), 7.5(\mathrm{t}, 4 \mathrm{H}), 9.8-9.9$ (2s). ${ }^{13}$ C NMR ppm (DMSO): 70.62, 73.08, 74.14, 78.19, 81.33, 86.05, 126.67, 126.97, 118.48, 118-59, 122.79-122.97, 129.11, 139.20-139.41, 152.89, 152.07. $\mathrm{C}_{20} \mathrm{H}_{20} \mathrm{~N}_{2} \mathrm{O}_{6}$ requires $\mathrm{C}, 62.49 ; \mathrm{H}, 5.24 ; \mathrm{N}, 7.29$. Found: $\mathrm{C}, 62.13 ; \mathrm{H}, 5.08 ; \mathrm{N}, 7.09$.

\subsubsection{Isosorbide-di-(4-nitrophenyl carbamate) (2e)}

A yellow powdered product (40\%): $\mathrm{mp} 262.2^{\circ} \mathrm{C}, \mathrm{IR}_{v \max }(\mathrm{KBr}): 1744(\mathrm{C}=0), 3383\left(2^{\circ} \mathrm{NH}\right) \mathrm{cm}^{-1} .{ }^{1} \mathrm{H} \mathrm{NMR} \delta(\mathrm{DMSO}): 3.89-3.91$ $(\mathrm{m}, 2 \mathrm{H}), 4.02-4.04(\mathrm{~m}, 2 \mathrm{H}), 4.56-4.57(\mathrm{~d}, 1 \mathrm{H}), 4.88-4.91(\mathrm{t}, 1 \mathrm{H}), 5.18-5.23(\mathrm{dq}, 2 \mathrm{H}), 7.68-7.72(\mathrm{~m}, 4 \mathrm{H}), 8.18-8.21(\mathrm{~m}, 4 \mathrm{H})$, $10.58(\mathrm{~s}, 2 \mathrm{H}) .{ }^{13} \mathrm{C}$ NMR ppm (DMSO): 70.69, 72.94, 74.77, 78.68, 81.36, 85.94, 118.00, 118.11, 125.38, 125.41, 142.08, 142.17, 145.69, 145.87, 152.63, 152.82. $\mathrm{C}_{20} \mathrm{H}_{18} \mathrm{O}_{10} \mathrm{~N}_{4}$ requires $\mathrm{C}, 50.6 ; \mathrm{H}, 3.8 ; \mathrm{N}, 11.8$. Found: $\mathrm{C}, 50.49 ; \mathrm{H} 3.68 ; \mathrm{N}, 12.05$.

\subsubsection{Isosorbide-di-(4-chlorophenylcarbamate) (2f)}

A white powdered product (37\%): $\mathrm{mp} 221.2^{\circ} \mathrm{C}, \mathrm{IR}_{v \max }(\mathrm{KBr}): 1705(\mathrm{C}=0), 3318\left(2^{\circ} \mathrm{NH}\right) \mathrm{cm}^{-1} .{ }^{1} \mathrm{H}$ NMR $\delta(\mathrm{DMSO}): 3.80-3.91$ $(\mathrm{m}, 2 \mathrm{H}), 3.99(\mathrm{~s}, 2 \mathrm{H}), 4.52-4.53(\mathrm{~d}, 1 \mathrm{H}, J=4.8 \mathrm{~Hz}), 4.83-4.86(\mathrm{t}, 1 \mathrm{H}, J=5.2 \mathrm{~Hz}), 5.13-5.18(\mathrm{dq}, 2 \mathrm{H}, J=3.2 \mathrm{~Hz}, J=5.2 \mathrm{~Hz})$, 7.32-7.36 (m, 4H), 7.48-7.52 (m, 4H), 10.00, $10.05(2 \mathrm{~s}, 2 \mathrm{H}) .{ }^{13} \mathrm{C} N M R$ ppm (DMSO): 70.61, 73.02, 74.29, 78.3, 81.31, 85.99, 119.94, 120.16, 126.44, 126.61, 128.98, 129.03, 138.22, 138.4, 152.82. $\mathrm{C}_{20} \mathrm{H}_{18} \mathrm{~N}_{2} \mathrm{O}_{6} \mathrm{Cl}_{2}$ requires $\mathrm{C}, 52.99 ; \mathrm{H}, 4.00 ; \mathrm{N}, 6.18$. Found: C, 52.73; H, 3.88; N, 5.74.

\subsubsection{Isosorbide-di-(benzylcarbamate) (2g)}

A white crystalline product (58\%): $\mathrm{mp} 160.4^{\circ} \mathrm{C}, \mathrm{IR}_{v \max }(\mathrm{KBr}): 1552$ (benzene), $1690(\mathrm{C}-\mathrm{O}), 3328\left(2^{\circ}\right.$ amine) $\mathrm{cm}^{-1} .{ }^{1} \mathrm{H} \mathrm{NMR} \delta$ (DMSO): 3.68-3.95 (2m, 4H,), 4.19-4.22 (m, 4H), 4.40-4.41 (d, 1H, J=4.8 Hz), 4.72-4.74 (t, 1H, J = 5.2 Hz), 4.97-5.03 (dq, $2 \mathrm{H}, \mathrm{J}=2.8 \mathrm{~Hz}), 7.22-7.35(\mathrm{~m}, 10 \mathrm{H}), 7.87,7.90(2 \mathrm{t}, 2 \mathrm{H}) .{ }^{13} \mathrm{C}$ NMR ppm (DMSO): 44.02, 44.11, 70.55, 73.19, 73.95, 78.1, 81.27, 86.01, 127.09, 127.4, 128.58, 128.65, 139.88-140.09, 155.89, 156.15. $\mathrm{C}_{22} \mathrm{H}_{24} \mathrm{~N}_{2} \mathrm{O}_{6}$ requires C, 64.07; $\mathrm{H}, 5.87 ; \mathrm{N}, 6.79$. Found: C, 63.99; H, 5.97; N, 6.74 .

\subsubsection{2-(Benzylaminocarbonyloxy)-5-keto-1,4:3,6-dianhydro-D-glucitol (3)}

A white crystalline compound (67\%): $\mathrm{mp} 107^{\circ} \mathrm{C}, \mathrm{IR}_{\text {umax }}(\mathrm{KBr}): 1599$ (benzene), 1725.0, $1774(\mathrm{C}=\mathrm{O})$, and $3326.4\left(2^{\circ} \mathrm{NH}\right)$ $\mathrm{cm}^{-1}$. ${ }^{1} \mathrm{H}$ NMR $\delta\left(\mathrm{CDCl}_{3}\right): 3.97(\mathrm{~d}, 1 \mathrm{H}, J=17.57 \mathrm{~Hz}, \mathrm{IsH}-1), 4.05-4.20\left(\mathrm{~m}, 3 \mathrm{H}, \mathrm{IsH}-1^{\prime}, \mathrm{IsH}-6, \mathrm{IsH}-6^{\prime}\right), 4.30(\mathrm{~d}, 1 \mathrm{H}, J=4.02 \mathrm{~Hz}, \mathrm{IsH}-$ 4), $4.39\left(\mathrm{~d}, 2 \mathrm{H}, J=6.02 \mathrm{~Hz}, \mathrm{CH}_{2}\right), 4.85(\mathrm{~d}, 1 \mathrm{H}, J=4.01 \mathrm{~Hz}, \mathrm{IsH}-3), 5.19(\mathrm{~s}, 1 \mathrm{H}, \mathrm{NH}), 5.36(\mathrm{~d}, 1 \mathrm{H}, J=2.51 \mathrm{~Hz}, \mathrm{IsH}-2), 7.22-7.40$ $(\mathrm{m}, 5 \mathrm{H}, \mathrm{ArH}) .{ }^{13} \mathrm{C} \mathrm{NMR} \mathrm{ppm}\left(\mathrm{CDCl}_{3}\right): 44.73,69.63,72.67,78.29,84.57,127.14,127.29,128.33,137.42,154.53,209.28$. $\mathrm{C}_{14} \mathrm{H}_{15} \mathrm{NO}_{5}$ requires $\mathrm{C}, 60.64 ; \mathrm{H}, 5.45 ; \mathrm{N}, 5.05$. Found: $60.73 ; \mathrm{H}, 5.43 ; \mathrm{N}, 4.67$.

\subsubsection{2-(Benzylaminocarbonyloxy)-5-deoxy-L-xylohex-6-enitol (7)}

To a solution of 2-(benzylaminocarbonyloxy)-5-O-trifluoromethanesulfonyl-1,4:3,6-dianhydro-D-glucitol (0.3647 mmol, $150 \mathrm{mg}$ ) in anhydrous toluene $(10 \mathrm{~mL})$ was added 1,5-diazabicyclo[4.3.0]non-5-ene $(0.4012 \mathrm{mmol}, 61.2 \mathrm{mg}, 0.06 \mathrm{~mL})$ and the $\mathrm{mixture}$ was stirred for $6 \mathrm{~h}$ at room temperature. The organic solvent was removed under vacuum and the crude mixture was diluted

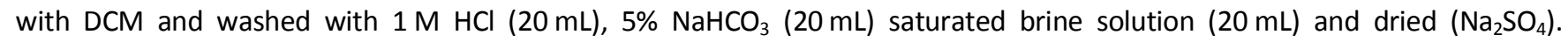
Purification by column chromatography over silica gel, using hexane and ethyl acetate (3:1) as eluent, afforded the title compound as white crystalline solid $(14.8 \mathrm{mg}, 15 \%)$. Mp $92^{\circ} \mathrm{C}$. IR $\operatorname{vmax}(\mathrm{KBr}): 1055.8(\mathrm{C}-\mathrm{O}-\mathrm{C}), 1611.0(\mathrm{C}=\mathrm{C}), 1719.3(\mathrm{C}=\mathrm{O})$, 2859.2, 2924.4 (C-H stretching), and $3328.0\left(2^{\circ}\right.$ amine) $\mathrm{cm}^{-1} .{ }^{1} \mathrm{H} \mathrm{NMR} \delta\left(\mathrm{CDCl}_{3}\right): 3.58(\mathrm{dd}, 1 \mathrm{H}, J=2.51$ and $10.56 \mathrm{~Hz}, \mathrm{IsH}-1), 3.99$ $\left(\mathrm{d}, 1 \mathrm{H}, J=6.02 \mathrm{~Hz}, \mathrm{IsH}-1^{\prime}\right), 4.40\left(\mathrm{~d}, 2 \mathrm{H}, J=6.02 \mathrm{~Hz}, \mathrm{CH}_{2}\right), 4.87(\mathrm{~d}, 1 \mathrm{H}, J=6.53 \mathrm{~Hz}, \mathrm{IsH}-3), 5.06(\mathrm{t}, 1 \mathrm{H}, J=2.51 \mathrm{~Hz}, \mathrm{IsH}-4), 5.13(\mathrm{~m}$, $1 \mathrm{H}, \mathrm{NH}), 5.20(\mathrm{~d}, 1 \mathrm{H}, J=2.01$ and $6.03 \mathrm{~Hz}, \mathrm{IsH}-2), 6.56(\mathrm{~d}, 1 \mathrm{H}, J=3.01 \mathrm{~Hz}, \mathrm{IsH}-6), 7.28-7.40(\mathrm{~m}, 5 \mathrm{H}, \mathrm{ArH})$.

\subsubsection{2-(Benzylaminocarbonyloxy)-5-ketoxime-1,4:3,6-dianhydro-D-glucitol (8)}

To a solution of $3(250 \mathrm{mg}, 0.9016 \mathrm{mmol})$ in methanol/water $(2: 1,6 \mathrm{~mL})$ was added 2 mol equiv of hydroxylamine hydrochloride ( $125.3 \mathrm{mg}, 1.80 \mathrm{mmol}$ ) ) and $5 \mathrm{~mol}$ equiv of $\mathrm{NaOAc}(4.508 \mathrm{mmol}, 369.8 \mathrm{mg})$. The reaction mixture was heated to $105{ }^{\circ} \mathrm{C}$ for $2 \mathrm{~h}$. The reaction mixture was evaporated to dryness under vacuum and the residue was dissolved in chloroform. Any excess water was dried $\left(\mathrm{Na}_{2} \mathrm{SO}_{4}\right)$ and the solution was filtered and evaporated. Purification by column chromatography yielded $176 \mathrm{mg}(66 \%)$ of a clear oil. $\mathrm{IR}_{v \max }(\mathrm{NaCl}): 1697.2,1720.1(\mathrm{C}=0), 2876.4,2928.3,(\mathrm{C}-\mathrm{H}$ stretching), and $3332.5(\mathrm{OH}) \mathrm{cm}^{-1} .{ }^{1} \mathrm{H}$ NMR $\delta\left(\mathrm{CDCl}_{3}\right): 3.90-4.10\left(\mathrm{~m}, 2 \mathrm{H}, \mathrm{IsH}-1, \mathrm{IsH}-1^{\prime}\right), 4.31\left(\mathrm{~d}, 2 \mathrm{H}, J=6.02 \mathrm{~Hz}, \mathrm{CH}_{2}\right), 4.50(\mathrm{~d}, 1 \mathrm{H}$, $J=15.56 \mathrm{~Hz}, \mathrm{IsH}-3), 4.54-4.70\left(\mathrm{~m}, 2 \mathrm{H}, \mathrm{IsH}-6, \mathrm{IsH}-6^{\prime}\right), 4.96(\mathrm{~d}, 1 \mathrm{H}, J=3.01 \mathrm{~Hz}, \mathrm{IsH}-4), 5.14(\mathrm{~s}, 1 \mathrm{H}, \mathrm{IsH}-2), 7.20-7.39(\mathrm{~m}, 5 \mathrm{H}$, 5ArH). ${ }^{13} \mathrm{C} \mathrm{NMR} \mathrm{ppm}\left(\mathrm{CDCl}_{3}\right): 44.42,69.13,72.21,78.53,80.32,86.50,127.17,127.28,128.48,139.14,156.58,159.85$. HRMS (M+23); $\mathrm{C}_{14} \mathrm{H}_{16} \mathrm{~N}_{2} \mathrm{O}_{5} \mathrm{Na}$ requires 315.0959. Found, 315.0957.

\subsubsection{2-(Benzylaminocarbonyloxy)-5-(phenylcarbonyloxyimino-)-1,4:3,6-dianhydro-D-glucitol (9)}

Compound $8(0.3421 \mathrm{mmol}, 100 \mathrm{mg})$ was dissolved in DCM $(10 \mathrm{~mL})$. Triethylamine $(0.376 \mathrm{mmol}, 38.0 \mathrm{mg}, 0.0524 \mathrm{~mL})$, benzoyl chloride $(0.3763 \mathrm{mmol}, 0.0437 \mathrm{~mL})$ and DMAP $(10 \%, 5 \mathrm{mg})$ were added. The reaction mixture was stirred overnight. Chloroform $(10 \mathrm{~mL})$ was added to the reaction vessel and the mixture was washed with $1 \mathrm{M} \mathrm{HCl}(20 \mathrm{~mL}), 5 \% \mathrm{NaHCO}$ $(20 \mathrm{~mL})$ saturated brine solution $(20 \mathrm{~mL})$ and dried $\left(\mathrm{Na}_{2} \mathrm{SO}_{4}\right)$. The solution was filtered and evaporated to give a white 
crystalline solid, which was recrystallised from $\mathrm{MeOH}$ to yield $106.0 \mathrm{mg}(78 \%)$ of a white crystalline product. $\mathrm{Mp} 91{ }^{\circ} \mathrm{C}, \mathrm{IR} \mathrm{R}_{\text {max }}$ $(\mathrm{KBr}): 1710.3,1725.9(\mathrm{C}=0), 2875.6,2979.5\left(\mathrm{C}-\mathrm{H}\right.$ stretching), and $3325.5\left(2^{\circ} \mathrm{NH}\right) \mathrm{cm}^{-1} .{ }^{1} \mathrm{H}$ NMR $\delta\left(\mathrm{CDCl}_{3}\right): 4.07-4.25(\mathrm{~m}$, $2 \mathrm{H}$, IsH-1, IsH-1'), $4.40\left(\mathrm{~d}, 2 \mathrm{H}, J=5.52 \mathrm{~Hz}, \mathrm{CH}_{2}\right), 4.70(\mathrm{~m}, 2 \mathrm{H}, \mathrm{IsH}-6$, IsH-6'), $4.87(\mathrm{~d}, 1 \mathrm{H}, J=16.57 \mathrm{~Hz}, \mathrm{IsH}-3), 5.20(\mathrm{~m}, 2 \mathrm{H}$, IsH4, NH), $5.35(\mathrm{~s}, 1 \mathrm{H}, \mathrm{IsH}-2), 7.23-7.43\left(\mathrm{~m}, 5 \mathrm{H}, 5 \mathrm{Ar}_{1} \mathrm{H}\right), 7.51\left(\mathrm{t}, 2 \mathrm{H}, J=7.53 \mathrm{~Hz}, \mathrm{Ar}_{2} \mathrm{H}-3 / \mathrm{Ar}_{2} \mathrm{H}-5\right), 7.65\left(\mathrm{t}, 1 \mathrm{H}, J=7.28 \mathrm{~Hz}, \mathrm{Ar}_{2} \mathrm{H}-4\right)$, $8.03\left(\mathrm{~d}, 2 \mathrm{H}, J=7.53 \mathrm{~Hz}, \mathrm{Ar}_{2} \mathrm{H}-2 / \mathrm{Ar}_{2} \mathrm{H}-6\right) .{ }^{13} \mathrm{C} \mathrm{NMR} \mathrm{ppm}\left(\mathrm{CDCl}_{3}\right): 44.75,69.47,72.72,77.60,79.74,86.30,127.16,127.27$, $127.57,128.25,128.33,129.27,133.37,137.46,154.53,162.61,168.02 . \mathrm{C}_{21} \mathrm{H}_{20} \mathrm{~N}_{2} \mathrm{O}_{6}$ requires $\mathrm{C}, 63.63 ; \mathrm{H}, 5.09 ; \mathrm{N}, 7.07$. Found: C, 63.69; H, 4.92; N, 6.77 .

\subsubsection{2-(Benzylaminocarbonyloxy)-5-deoxy, 5-dehydro-((ethyloxycarbonyl)ene-)-1,4:3,6-dianhydro-D-glucitol (12)}

A solution of $3(0.902 \mathrm{mmol}, 250 \mathrm{mg})$ in DCM/THF $(1: 1,10 \mathrm{~mL})$ was cooled to $0{ }^{\circ} \mathrm{C}$ on ice in a Dewar flask and kept under an atmosphere of $\mathrm{N}_{2}$ gas. Carbethoxymethylene(triphenylphosphorane) $(0.9918 \mathrm{mmol}, 314.6 \mathrm{mg})$ was added to the solution and the mixture was stirred for $6 \mathrm{~h}$. The reaction mixture was evaporated to dryness under vacuum and the residue purified by column chromatography using hexane and ethyl acetate $(2: 1)$ as eluent yielded $141.7 \mathrm{mg}$ of the title compounds as a white crystalline solid (45\%). Mp $121^{\circ} \mathrm{C}$. $\mathrm{IR}_{\text {vmax }}(\mathrm{KBr}): 1721.4(\mathrm{C}=\mathrm{O})$, and $3324.8\left(2^{\circ} \mathrm{NH}\right) \mathrm{cm}^{-1} .{ }^{1} \mathrm{H}$ NMR $\delta\left(\mathrm{CDCl}_{3}\right): 1.30(\mathrm{t}, 3 \mathrm{H}$, $\left.J=7.31 \mathrm{~Hz}, \mathrm{CH}_{3}\right), 4.00(\mathrm{~m}, 2 \mathrm{H}, \mathrm{IsH}-1), 4.20\left(\mathrm{~m}, 2 \mathrm{H},-\mathrm{CH}_{2} \mathrm{CH}_{3}\right), 4.38\left(\mathrm{~d}, 2 \mathrm{H}, J=6.02 \mathrm{~Hz},-\mathrm{NCH}_{2} \mathrm{Ar}\right), 4.55(\mathrm{~d}, 1 \mathrm{H}, J=4.10 \mathrm{~Hz}$, IsH3), $4.74(\mathrm{dd}, 1 \mathrm{H}, J=2.92$ and $17.54 \mathrm{~Hz}$, IsH-4), $4.97(\mathrm{~m}, 2 \mathrm{H}$, IsH-6, IsH-6'), $5.15(\mathrm{~s}, 1 \mathrm{H}, \mathrm{NH}), 5.25(\mathrm{~s}, 1 \mathrm{H}, \mathrm{IsH}-2), 6.11(\mathrm{~s}, 1 \mathrm{H},-$ $\mathrm{C}=\mathrm{CH}-), 7.23-7.40(\mathrm{~m}, 5 \mathrm{H}, 5 \mathrm{ArH}) .{ }^{13} \mathrm{C} \mathrm{NMR} \mathrm{ppm}\left(\mathrm{CDCl}_{3}\right): 13.79\left(\mathrm{CH}_{3}\right), 44.69\left(-\mathrm{NCH}_{2} \mathrm{Ar}\right), 60.16\left(-\mathrm{CH}_{2} \mathrm{CH}_{3}\right), 70.92$ (IsC-1), 71.77 (IsC-6), 78.24 (IsC-2), 83.28 (IsC-4), 84.74 (IsC-3), 116.12 (-C=CH-), 127.12 (ArC-4), 127.22 (Ar-2/Ar-6), 128.29 (ArC3/ArC-5), 137.59 (ArC-1), 154.71 (-NC(O)O-), 158.13 (ArC-5), $165.30\left(-\mathrm{C}(\mathrm{O}) \mathrm{CH}_{2} \mathrm{CH}_{3}\right) . \mathrm{C}_{18} \mathrm{H}_{21} \mathrm{NO}_{6}$ requires $\mathrm{C}, 62.24 ; \mathrm{H}, 6.09 ; \mathrm{N}$, 4.03. Found: $\mathrm{C}, 62.20 ; \mathrm{H}, 6.08, \mathrm{~N}, 3.98$.

\subsubsection{7-exo-(Benzylaminocarbonyloxy)-3-oxo-2,5,9-trioxabicyclo [4.3.0] nonane (10)}

A solution of $3(0.9016 \mathrm{mmol}, 250 \mathrm{mg})$ in DCM was stirred and cooled to $0^{\circ} \mathrm{C}$. Chloroperbenzoic acid $(500 \mathrm{mg})$ and $\mathrm{NaOAC}$ $(6.0953 \mathrm{mmol}, 500 \mathrm{mg})$ were added and the mixture stirred overnight. The reaction was monitored by TLC. The solvent was evaporated and the crude product was purified by flash chromatography (DCM/ethyl acetate, 9:1) to give $102 \mathrm{mg}$ (38\%) of the title product as a clear oil. $\mathbb{I R}_{v \max }(\mathrm{NaCl}): 1719.5,1725.1(\mathrm{C}=0), 2953.0\left(\mathrm{C}-\mathrm{H}\right.$ stretching), and $3328.3\left(2^{\circ} \mathrm{NH}\right) \mathrm{cm}^{-1}$. ${ }^{1} \mathrm{H}$ NMR $\delta\left(\mathrm{CDCl}_{3}\right): 4.03\left(\mathrm{~m}, 2 \mathrm{H}\right.$, IsH-1, IsH-1'), 4.28-4.43 (m, 5H, IsH-6, IsH-6', IsH-3, $\left.\mathrm{CH}_{2}\right), 5.24(\mathrm{~m}, 2 \mathrm{H}, \mathrm{IsH}-2, \mathrm{NH}), 5.86(\mathrm{~d}, 1 \mathrm{H}$, $J=3.52 \mathrm{~Hz}$, IsH-4), 7.22-7.42 (m, 5H, 5ArH). ${ }^{13} \mathrm{C}$ NMR ppm $\left(\mathrm{CDCl}_{3}\right): 44.76\left(\mathrm{CH}_{2}\right), 62.87$ (IsC-1), 72.05 (IsC-6), 77.04 (IsC-2), 77.40 (IsC-3), 100.89 (IsC-4), 127.15 (ArC-4), 127.37 (Ar-2/Ar-6), 128.36 (ArC-3/ArC-5), 137.29 (ArC-1), 154.41 (CO), 165.29 (ArC-5). HRMS $(\mathrm{M}+23) ; \mathrm{C}_{14} \mathrm{H}_{15} \mathrm{NO}_{6} \mathrm{Na}$ requires 316.0798. Found, 316.0881 .

\subsubsection{N-Methyl-7-exo-(benzylaminocarbonyloxy-)-3-oxo-5,9-dioxa-2-azabicyclo[4.3.0] nonane (11)}

To a solution of $3(0.9016 \mathrm{mmol}, 250 \mathrm{mg})$ in anhydrous ethanol $(6 \mathrm{~mL})$ was added 4 mol equiv of $N$-methylhydroxylamine $\mathrm{HCl}(3.606 \mathrm{mmol}, 301.2 \mathrm{mg}$ ) and $6 \mathrm{~mol}$ equiv of sodium acetate $(5.4094 \mathrm{mmol}, 443.7 \mathrm{mg})$. The reaction mixture was stirred for $4 \mathrm{~h}$. The reaction mixture then filtered and evaporated. The crude intermediate product was purified by flash chromatography yielding a yellow viscous oil, which was diluted in pyridine $(7 \mathrm{~mL})$ and cooled to $0{ }^{\circ} \mathrm{C}$. The reaction mixture was stirred and kept under an atmosphere of $N_{2}$ gas. $p$-Toluenesulfonyl chloride $(1.56 \mathrm{mmol}, 300 \mathrm{mg})$ was added to the mixture and stirred for $6 \mathrm{~h}$. The crude product was purified by flash chromatography (DCM/ethyl acetate, 9:1) to give $96.5 \mathrm{mg}(34 \%)$ of the title product as a clear oil. $\mathrm{IR}_{v \max }(\mathrm{NaCl}): 1606.7(\mathrm{C}-\mathrm{N}), 1718.7,1721.4(\mathrm{C}=0), 3321.5\left(2^{\circ} \mathrm{NH}\right) \mathrm{cm}^{-1} .{ }^{1} \mathrm{H}$ NMR $\delta\left(\mathrm{CDCl}_{3}\right): 3.06\left(\mathrm{~s}, 3 \mathrm{H}, \mathrm{CH}_{3}\right), 3.90(\mathrm{~d}, 1 \mathrm{H}, J=10.36 \mathrm{~Hz}, \mathrm{IsH}-1) 4.05(\mathrm{~d}, 1 \mathrm{H}, J=16.06 \mathrm{~Hz}, \mathrm{IsH}-6), 4.19(\mathrm{~d}, 1 \mathrm{H}, J=2.51 \mathrm{~Hz}$, IsH-3) $4.25\left(\mathrm{~d}, 1 \mathrm{H}, J=16.57 \mathrm{~Hz}\right.$, IsH-6') $4.30-4.40\left(\mathrm{~m}, 3 \mathrm{H}, \mathrm{IsH}-1^{\prime}, \mathrm{CH}_{2}\right), 4.98(\mathrm{~d}, 1 \mathrm{H}, J=2.51 \mathrm{~Hz}, \mathrm{IsH}-4), 5.17(\mathrm{~d}, 1 \mathrm{H}, J=4.02$, IsH-2), 5.26-5.37 (s, $1 \mathrm{H}, \mathrm{NH}), 7.23-7.40(\mathrm{~m}, 5 \mathrm{H}, \mathrm{ArH}) .{ }^{13} \mathrm{C} \mathrm{NMR} \mathrm{ppm}\left(\mathrm{CDCl}_{3}\right): 32.01\left(\mathrm{CH}_{3}\right), 45.19\left(\mathrm{CH}_{2}\right), 66.24(\mathrm{IsC}-1), 71.17$ (IsC-6), 77.28 (IsC-2), 77.43 (IsC-3), 87.47 (IsC-4), 127.14 (ArC-4), 127.31 (Ar-2/Ar-6), 128.33 (ArC-3/ArC-5), 137.43 (ArC-1), 154.45 (CO), 166.12 (ArC-5). HRMS (M+23); $\mathrm{C}_{15} \mathrm{H}_{18} \mathrm{~N}_{2} \mathrm{O}_{6} \mathrm{Na}$ requires 329.1115. Found, 329.1212.

\subsubsection{5-O-Toluenesulfonyl-1,4:3,6-dianhydro-L-iditol}

Isoiodide $14(6.84 \mathrm{mmol}, 1 \mathrm{~g})$ and $p$-toluenesulfonyl chloride $(6.84 \mathrm{mmol}, 1.30 \mathrm{~g})$ were dissolved in acetone $(20 \mathrm{~mL})$. The reaction vessel was cooled to $0{ }^{\circ} \mathrm{C}$ following the method outlined for the preparation of esters. Recrystallisation from ethanol yielded the title compound as a white crystalline product $(1.27 \mathrm{~g}, 62 \%) .{ }^{1} \mathrm{H}$ NMR $\delta\left(\mathrm{CDCl}_{3}\right): 2.48\left(\mathrm{~s}, 3 \mathrm{H}, \mathrm{CH}_{3}\right), 3.76-$ $3.90(\mathrm{~m}, 4 \mathrm{H}$, IsH-6, IsH-1, IsH-1'), $3.98(\mathrm{~d}, 1 \mathrm{H}, J=11.04 \mathrm{~Hz}$, IsH-6'), $4.34(\mathrm{~s}, 1 \mathrm{H}, \mathrm{IsH}-2), 4.56$ (d, $1 \mathrm{H}, J=4.31 \mathrm{~Hz}, \mathrm{IsH}-3), 4.65$ (d, $1 \mathrm{H}, J=3.51 \mathrm{~Hz}, \mathrm{IsH}-4), 4.90(\mathrm{~m}, 1 \mathrm{H}, J=3.52 \mathrm{~Hz}, \mathrm{IsH}-5), 7.39$ (d, 2H, J = 8.03, ArH-3/ArH-5), 7.82 (d, 2H, J = 8.03, ArH-2/ArH-6). ${ }^{13} \mathrm{CNMR} \mathrm{ppm}\left(\mathrm{CDCl}_{3}\right): 21.69\left(\mathrm{CH}_{3}\right), 72.03$ (IsC-6), 74.72 (IsC-1), 75.71 (IsC-2), 83.08 (IsC-5), 84.81 (IsC-4), 87.57 (IsC-3), 127.84 (ArC-2/ArC-6), 130.09 (ArC-3/ArC-5), 133.10 (ArC-1), 145.37 (ArC-4).

\subsubsection{5-Deoxy-5-azido-1,4:3,6-dianhydro-D-glucitol}

5-O-(Toluenesulfonyl)-1,4:3,6-dianhydro-L-iditol $(4.16 \mathrm{mmol}, 1.25 \mathrm{~g}$ ) was dissolved in a minimum volume of DMSO $(7.5 \mathrm{~mL})$. Excess sodium azide $(20.8 \mathrm{mmol}, 1.36 \mathrm{~g})$ was added to form a slurry. The mixture was heated to $125^{\circ} \mathrm{C}$ and stirred for $24 \mathrm{~h}$. The mixture was partitioned between ethyl acetate and water and the organic extract washed several times. The crude product was purified by flash chromatography giving a white solid, which was recrystallised to afford the title compound as a white crystalline product $(514.4 \mathrm{mg}, 72 \%) .{ }^{1} \mathrm{H}$ NMR $\delta\left(\mathrm{CDCl}_{3}\right): 3.13(\mathrm{~d}, 1 \mathrm{H}, J=4.52 \mathrm{~Hz}, \mathrm{OH}), 3.64(\mathrm{~m}, 1 \mathrm{H}, \mathrm{IsH}-5), 3.85-4.00$ 
(m, $4 \mathrm{H}, \mathrm{IsH}-1, \mathrm{IsH}-6), 4.32(\mathrm{~s}, 1 \mathrm{H}, \mathrm{IsH}-2), 4.42\left(\mathrm{~d}, 1 \mathrm{H}, J=4.02 \mathrm{~Hz}\right.$, IsH-3), $4.82(\mathrm{~d}, 1 \mathrm{H}, J=4.52 \mathrm{~Hz}, \mathrm{IsH}-4) .{ }^{13} \mathrm{C} \mathrm{NMR} \mathrm{ppm}\left(\mathrm{CDCl}_{3}\right)$ : 61.80 (IsC-5), 69.25 (IsC-6), 75.43 (IsC-1), 75.86 (IsC-2), 82.04 (IsC-4), 88.21 (IsC-3).

\subsubsection{2-(Benzylaminocarbonyloxy)-5-deoxy-5-phenylcarbonylamino-1,4:3,6-dianhydro-D-glucitol (16)}

To a solution of 5-deoxy-5-azido-1,4:3,6-dianhydro-D-glucitol $(2.92 \mathrm{mmol}, 500 \mathrm{mg})$, in DCM was added triethylamine $(3.21 \mathrm{mmol}, 324.6 \mathrm{mg}, 0.447 \mathrm{~mL})$, benzyl isocyanate $(3.21 \mathrm{mmol})$ and DMAP $(0.4092 \mathrm{mmol}, 50 \mathrm{mg})$. The reaction was monitored by TLC. The mixture was cooled upon completion of the reaction and methanol $(10 \mathrm{~mL})$ was added to remove excess isocyanate. The mixture was heated for a further $15 \mathrm{~min}$ at $105^{\circ} \mathrm{C}$ and cooled to room temperature. All organic solvent was removed giving a clear oil which was purified by column chromatography using hexane and ethyl acetate (3:1 and 1:1) as eluent to isolate the primary product as a white crystalline solid. The white crystalline solid was dissolved in ethyl acetate/methanol (1:1, $15 \mathrm{~mL})$. A spatula tip-full of $10 \%$ palladium on activated carbon was added to the solution. Air was expelled from the flask and the mixture was kept under an atmosphere of hydrogen gas and stirred for $24 \mathrm{~h}$. The palladium catalyst was removed by filtration and the filtrate was collected and evaporated under vacuum to give a clear oil. This oil was diluted with $\mathrm{DCM}(10 \mathrm{~mL})$ and excess triethylamine $(3.59 \mathrm{mmol}, 363.0 \mathrm{mg}, 0.5 \mathrm{~mL})$, benzoyl chloride $(3.59 \mathrm{mmol}, 505.2 \mathrm{mg}, 0.4172 \mathrm{~mL})$ and DMAP $(0.4092 \mathrm{mmol}, 50 \mathrm{mg})$ were added to the reaction vessel. The reaction mixture was stirred for $4 \mathrm{~h}$. DCM $(10 \mathrm{~mL})$ was added to the reaction vessel and the mixture was washed with $1 \mathrm{M} \mathrm{HCl}$ $(20 \mathrm{~mL}), 5 \% \mathrm{NaHCO}_{3}(20 \mathrm{~mL})$ saturated brine solution $(20 \mathrm{~mL})$ and dried over anhydrous sodium sulfate $(1 \mathrm{~g})$. Purification by column chromatography, using hexane and ethyl acetate (2:1) as eluent afforded the title compound as a white crystalline solid (218.5 mg, 19\%). Mp $164{ }^{\circ} \mathrm{C} . \mathrm{IR}_{v \max }(\mathrm{KBr}): 1698.6,1720.1(\mathrm{C}=\mathrm{O})$, and $3326.5,3350.6 \mathrm{~cm}^{-1} .{ }^{1} \mathrm{H} \mathrm{NMR} \delta\left(\mathrm{CDCl}_{3}\right): 3.45(\mathrm{t}$, $1 \mathrm{H}, J=8.79 \mathrm{~Hz}, \mathrm{IsH}-6), 4.02-4.11\left(\mathrm{~m}, 2 \mathrm{H}\right.$, IsH-1, IsH-1'), $4.32\left(\mathrm{t}, 1 \mathrm{H}, J=8.03 \mathrm{~Hz}, \mathrm{IsH}-6^{\prime}\right), 4.39\left(\mathrm{~d}, 2 \mathrm{H}, J=6.02 \mathrm{~Hz}, \mathrm{CH}_{2}\right), 4.55-$ $4.77(\mathrm{~m}, 3 \mathrm{H}$, IsH-3, IsH-4, IsH-5), $5.15(\mathrm{~s}, 1 \mathrm{H}, \mathrm{NH}), 5.24(\mathrm{~s}, 1 \mathrm{H}, \mathrm{IsH}-2), 6.74(\mathrm{~d}, 1 \mathrm{H}, J=7.02 \mathrm{~Hz}, \mathrm{NH}$-benzylamide), $7.23-7.40(\mathrm{~m}$, $\left.5 \mathrm{H}, 5 \mathrm{Ar}_{1} \mathrm{H}\right), 7.47\left(\mathrm{~m}, 2 \mathrm{H}, \mathrm{Ar}_{2} \mathrm{H}-3 / \mathrm{Ar}_{2} \mathrm{H}-5\right), 7.53\left(\mathrm{~m}, 1 \mathrm{H}, \mathrm{Ar}_{2} \mathrm{H}-4\right), 7.81\left(\mathrm{~m}, 2 \mathrm{H}, \mathrm{Ar}_{2} \mathrm{H}-2 / \mathrm{Ar}_{2} \mathrm{H}-6\right) .{ }^{13} \mathrm{C} \mathrm{NMR} \mathrm{ppm}\left(\mathrm{CDCl}_{3}\right): 44.73$ $\left(\mathrm{CH}_{2}\right), 52.83$ (IsC-5), 70.77 (IsC-6), 73.44 (IsC-1), 78.55 (IsC-2), 81.36 (IsC-4), 85.37 (IsC-2), $126.59\left(\mathrm{Ar}_{2} \mathrm{C}-2 / \mathrm{Ar}_{2} \mathrm{C}-6\right), 127.14$ $\left(\mathrm{Ar}_{1} \mathrm{C}-4\right), 127.26\left(\mathrm{Ar}_{1} \mathrm{C}-2 / \mathrm{Ar}_{1} \mathrm{C}-6\right), 128.19\left(\mathrm{Ar}_{2} \mathrm{C}-3 / \mathrm{Ar}_{2} \mathrm{C}-5\right), 128.32\left(\mathrm{Ar}_{1} \mathrm{C}-3 / \mathrm{Ar}_{1} \mathrm{C}-5\right), 131.36\left(\mathrm{Ar}_{2} \mathrm{C}-4\right), 133.35\left(\mathrm{Ar}_{2} \mathrm{C}-1\right), 137.53$ $\left(\mathrm{Ar}_{1} \mathrm{C}-1\right), 154.65\left(-\mathrm{Ar}_{1} \mathrm{CH}_{2} \mathrm{NC}(\mathrm{O}) \mathrm{O}-\right), 166.33\left(-\mathrm{NC}(\mathrm{O}) \mathrm{Ar}_{2}\right)$. HRMS (M+23); $\mathrm{C}_{21} \mathrm{H}_{22} \mathrm{~N}_{2} \mathrm{O}_{5} \mathrm{Na}$ requires 405.1427; found, 405.1367.

\subsubsection{2-(Benzylaminocarbonyloxy)-5-O-benzyl-1,4:3,6-dianhydro-D-glucitol (18a)}

2-O-(t-(Butyl)-dimethylsilyl-)-1,4:3,6-dianhydro-D-glucitol 17 (1.1521 mmol, $300 \mathrm{mg}$ ) and excess $\mathrm{NaH}$ (100 mg of 65\% NaH in an oil suspension) was placed under an atmosphere of $\mathrm{N}_{2}$ gas. Anhydrous THF was added to the flask and the mixture was stirred for $30 \mathrm{~min}$. Excess benzyl bromide $(3.363 \mathrm{mmol}, 575 \mathrm{mg}, 0.4 \mathrm{~mL}$ ) was added dropwise over $15 \mathrm{~min}$ and the reaction mixture was stirred for a further $24 \mathrm{~h}$. The mixture was diluted with water $(25 \mathrm{~mL})$, extracted with ethyl acetate $(3 \times 25 \mathrm{~mL})$ and dried over anhydrous sodium sulfate. The organic portions were collected and evaporated to dryness to give a clear oil. The remaining excess benzyl bromide was eliminated from the mixture by column chromatography, which yielded a clear oil. The oil was diluted with THF $(10 \mathrm{~mL})$. Excess $0.1 \mathrm{M}$ tetrabutylammonium fluoride $(1.2 \mathrm{~mL})$ was added and the mixture was stirred at room temperature for $15 \mathrm{~min}$. The organic solvent was evaporated to dryness under vacuum giving a brown oil. DCM $(10 \mathrm{~mL})$ was added to the reaction vessel and the solution was stirred at room temperature. To the mixture was added excess $\mathrm{Et}_{3} \mathrm{~N}(1.79 \mathrm{mmol}, 181.5 \mathrm{mg}, 0.250 \mathrm{~mL})$, benzyl isocyanate $(2.0240 \mathrm{mmol}, 269.5 \mathrm{mg}, 0.25 \mathrm{~mL})$ and $\mathrm{DMAP}$ $(0.245 \mathrm{mmol}, 30 \mathrm{mg})$. The mixture was heated to $105^{\circ} \mathrm{C}$ for $2 \mathrm{~h}$. The mixture was cooled upon completion of the reaction and methanol $(10 \mathrm{~mL})$. The mixture was heated for a further $15 \mathrm{~min}$ at $105^{\circ} \mathrm{C}$ and cooled to room temperature. The reaction mixture was evaporated to dryness giving a clear oil to which was added $\mathrm{DCM}(20 \mathrm{~mL})$ and washed with $1 \mathrm{M} \mathrm{HCl}$ $(20 \mathrm{~mL}), 5 \% \mathrm{NaHCO}_{3}(20 \mathrm{~mL})$, saturated brine solution $(20 \mathrm{~mL})$ and dried with anhydrous sodium sulfate. The solution was filtered into a round bottom flask and the organic solvent was evaporated to dryness under vacuum giving a white crystalline compound. Purification by flash chromatography afforded the title compound as a white crystalline product (108.6 mg, 25\%). Mp $107^{\circ} \mathrm{C}, I_{\text {vmax }}(\mathrm{KBr}): 1697.2(\mathrm{C}=\mathrm{O})$ ), and $3349 \mathrm{~cm}^{-1} .{ }^{1} \mathrm{H} \mathrm{NMR} \delta\left(\mathrm{CDCl}_{3}\right): 3.65(\mathrm{t}, 1 \mathrm{H}, \mathrm{J}=8.28 \mathrm{~Hz}, \mathrm{IsH}-6)$, $3.90\left(\mathrm{dd}, 1 \mathrm{H}, J=6.53\right.$ and $\left.8.54 \mathrm{~Hz}, \mathrm{IsH}-6^{\prime}\right), 4.04-4.15\left(\mathrm{~m}, 3 \mathrm{H}, \mathrm{IsH}-5, \mathrm{IsH}-1, \mathrm{IsH}-1^{\prime}\right), 4.39\left(\mathrm{~d}, 2 \mathrm{H}, J=6.02 \mathrm{~Hz}, \mathrm{CH}_{2}\right), 4.53(\mathrm{~d}, 1 \mathrm{H}$, $J=4.02 \mathrm{~Hz}, \mathrm{IsH}-3$ ), 4.59 (d, $1 \mathrm{~h}, J=12.04 \mathrm{~Hz}, \mathrm{OCH}_{2} \mathrm{Ar}_{1}$ ), $4.68(\mathrm{t}, 1 \mathrm{H}, J=4.27 \mathrm{~Hz}, \mathrm{IsH}-4), 4.78\left(\mathrm{~d}, 1 \mathrm{H}, J=12.04 \mathrm{~Hz}_{1}, \mathrm{OCH}_{2} \mathrm{Ar}_{2}\right)$, $5.08(\mathrm{~s}, 1 \mathrm{H}, \mathrm{NH}), 5.19(\mathrm{~d}, 1 \mathrm{H}, J=3.01 \mathrm{~Hz}, \mathrm{IsH}-2), 7.23-7.43\left(\mathrm{~m}, 10 \mathrm{H}, 5 \mathrm{Ar}_{1} \mathrm{H}, 5 \mathrm{Ar}_{2} \mathrm{H}\right) .{ }^{13} \mathrm{C} \mathrm{NMR} \mathrm{ppm}\left(\mathrm{CDCl}_{3}\right): 45.06\left(\mathrm{CH}_{2}\right), 69.82$ (IsC-6), $72.05\left(\mathrm{OCH}_{2} \mathrm{Ar}_{2}\right), 73.55$ (IsC-1), 78.58 (IsC-2), 78.68 (IsC-5), 80.06 (IsC-4), 85.54 (IsC-3), $127.12\left(\mathrm{Ar}_{1} \mathrm{C}-4\right), 127.20\left(\mathrm{Ar}_{1} \mathrm{C}-\right.$ 2/Ar $\left.{ }_{1} \mathrm{C}-6\right), 127.52\left(\mathrm{Ar}_{2} \mathrm{C}-2 / \mathrm{Ar}_{2} \mathrm{C}-6 / \mathrm{Ar}_{2} \mathrm{C}-4\right), 128.06\left(\mathrm{Ar}_{2} \mathrm{C}-3 / \mathrm{Ar}_{2} \mathrm{C}-5\right), 128.29\left(\mathrm{Ar}_{1} \mathrm{C}-3 / \mathrm{Ar}_{1} \mathrm{C}-5\right), 137.19\left(\mathrm{Ar}_{2} \mathrm{C}-1\right), 137.64\left(\mathrm{Ar}_{1} \mathrm{C}-1\right)$, 154.79 (CO). $\mathrm{C}_{21} \mathrm{H}_{23} \mathrm{NO}_{5}$ requires $\mathrm{C}, 68.28 ; \mathrm{H}, 6.28 ; \mathrm{N}, 3.79$. Found: $\mathrm{C}, 68.22 ; \mathrm{H}, 6.27 ; \mathrm{N}, 3.69$.

\subsubsection{2-(Benzylaminocarbonyloxy)-5-O-(phenylpropyloxy)-1,4:3,6-dianhydro-D-glucitol (18b)}

Method was as for 18a: (88.4 mg, 19\%). Mp $97^{\circ} \mathrm{C} . \mathrm{IR}_{v \max }(\mathrm{KBr}): 1691.2(\mathrm{C}=0)$, and $3328.5\left(2^{\circ}\right.$ amine) $\mathrm{cm}^{-1} .{ }^{1} \mathrm{H} \mathrm{NMR} \delta$ $\left(\mathrm{CDCl}_{3}\right): 1.97\left(\mathrm{~m}, 2 \mathrm{H}, \mathrm{OCH}_{2} \mathrm{CH}_{2} \mathrm{CH}_{2} \mathrm{Ar}_{2}\right), 2.73\left(\mathrm{t}, 2 \mathrm{H}, \mathrm{J}=7.78 \mathrm{~Hz}, \mathrm{OCH}_{2} \mathrm{CH}_{2} \mathrm{CH}_{2} \mathrm{Ar}_{2}\right), 3.48\left(\mathrm{~m}, 1 \mathrm{H}, \mathrm{OCH}_{2} \mathrm{CH}_{2} \mathrm{CH}_{2} \mathrm{Ar}_{2}\right), 3.63(\mathrm{t}, 1 \mathrm{H}$, $J=7.78 \mathrm{~Hz}, \mathrm{IsH}-6), 3.71\left(\mathrm{~m}, 1 \mathrm{H}, \mathrm{OCH}_{2} \mathrm{CH}_{2} \mathrm{CH}_{2} \mathrm{Ar}_{2}{ }^{\prime}\right), 3.92-4.15\left(\mathrm{~m}, 4 \mathrm{H}, \mathrm{IsH}-6^{\prime}, \mathrm{IsH}-5, \mathrm{IsH}-1, \mathrm{IsH}-1^{\prime}\right), 4.38\left(\mathrm{~d}, 2 \mathrm{H}, J=6.02 \mathrm{~Hz}, \mathrm{CH}_{2}\right)$, $4.54(\mathrm{~d}, 1 \mathrm{H}, J=4.02 \mathrm{~Hz}$, IsH-3), $4.64(\mathrm{t}, 1 \mathrm{H}, J=4.02 \mathrm{~Hz}, \mathrm{IsH}-4), 5.11(\mathrm{~s}, 1 \mathrm{H}, \mathrm{NH}), 5.19(\mathrm{~d}, 1 \mathrm{H}, J=3.51 \mathrm{~Hz}, \mathrm{IsH}-2), 7.17-7.40(\mathrm{~m}$, $\left.10 \mathrm{H}, 5 \mathrm{Ar}_{1} \mathrm{H}, 5 \mathrm{Ar}_{2} \mathrm{H}\right) .{ }^{13} \mathrm{C} \mathrm{NMR}$ ppm $\left(\mathrm{CDCl}_{3}\right): 31.21\left(\mathrm{OCH}_{2} \mathrm{CH}_{2} \mathrm{CH}_{2} \mathrm{Ar}_{2}\right), 32.11\left(\mathrm{OCH}_{2} \mathrm{CH}_{2} \mathrm{CH}_{2} \mathrm{Ar}_{2}\right), 45.06\left(\mathrm{CH}_{2}\right), 69.94$ $\left(\mathrm{OCH}_{2} \mathrm{CH}_{2} \mathrm{CH}_{2} \mathrm{Ar}_{2}\right.$ ), 70.06 (IsC-6), 73.94 (IsC-1), 78.96 (IsC-2), 80.33 (IsC-5), 80.41 (IsC-4), 85.95 (IsC-3), 125.77 (Ar 2 C-4), 127.51 $\left(\mathrm{Ar}_{1} \mathrm{C}-4\right), 127.59\left(\mathrm{Ar}_{1} \mathrm{C}-2 / \mathrm{Ar}_{1} \mathrm{C}-6\right), 128.29\left(\mathrm{Ar}_{1} \mathrm{C}-3 / \mathrm{Ar}_{1} \mathrm{C}-5\right), 128.41\left(\mathrm{Ar}_{2} \mathrm{C}-2 / \mathrm{Ar}_{2} \mathrm{C}-6\right), 128.68\left(\mathrm{Ar}_{2} \mathrm{C}-3 / \mathrm{Ar}_{2} \mathrm{C}-5\right), 138.05\left(\mathrm{Ar}_{1} \mathrm{C}-1\right)$, 141.70 ( $\left.\mathrm{Ar}_{2} \mathrm{C}-1\right), 155.21$ (CO). $\mathrm{C}_{23} \mathrm{H}_{27} \mathrm{NO}_{5}$ requires $\mathrm{C}, 69.50 ; \mathrm{H}, 6.85 ; \mathrm{N}, 3.52$. Found: $\mathrm{C}, 69.46 ; \mathrm{H}, 6.88 ; \mathrm{N}, 3.39$. 


\subsection{Determination of cholinesterase activity and inhibition}

$1 \mathrm{M}$ solutions of each inhibitor were prepared in $10 \mathrm{~mL}$ of acetonitrile/distilled water (1:1). [25 $\mu \mathrm{L}$ of a $1 \mathrm{M}$ inhibitor solution in $250 \mu \mathrm{L}$ of test solution (see below) gave an inhibitor concentration of $100 \mathrm{mM}$ ]. Butyrylthiocholine iodide (BTCl): $\mathrm{BTCl}$ $(15.9 \mathrm{mg})$ was dissolved in $10 \mathrm{~mL}$ of phosphate buffer $\mathrm{pH}$ 8.0. [ $25 \mu \mathrm{L}$ of this solution in $250 \mu \mathrm{L}$ of test solution will give a concentration of $0.5 \mathrm{mM}$ ]. Acetylthiocholine iodide (ATCI): ATCl $(14.5 \mathrm{mg})$ was dissolved in $10 \mathrm{~mL}$ of phosphate buffer pH 8.0. [ $25 \mu \mathrm{L}$ of this solution in $250 \mu \mathrm{L}$ of test solution will give a concentration of $0.5 \mathrm{mM}$ ]. For human plasma BuChE, human blood samples were collected by venepuncture into Li-Heparin Sarstedt Monovette tubes $(9 \mathrm{~mL})$. Plasma was obtained by centrifugation at $10,000 \mathrm{rpm}$ for $5 \mathrm{~min}$. Plasma was stored at $2-6^{\circ} \mathrm{C}$. A plasma solution for the activity/inhibition assay was prepared by diluting $1 \mathrm{~mL}$ of plasma to $20 \mathrm{~mL}$ with phosphate buffer $\mathrm{pH} 8.0$.

AChE: $10 \mu \mathrm{L}$ of electric eel AChE was diluted to $10 \mathrm{~mL}$ with phosphate buffer $\mathrm{pH}$ 8.0. HuBuChE activity was measured in replicate samples using a 96-well plate reader. The total volume of test solution in each well was $250 \mu \mathrm{L}$. This consisted of $25 \mu \mathrm{L}$ of plasma solution, $175 \mu \mathrm{L}$ of phosphate buffer pH 8.0, $25 \mu \mathrm{L}$ of DTNB solution [0.5 mM] and $25 \mu \mathrm{L}$ of acetonitrile/distilled water (1:1). The 96-well plate was incubated for $30 \mathrm{~min}$ before $25 \mu \mathrm{L}$ of BTCl solution [0.5 mM] was added and the reaction was measured at $412 \mathrm{~nm}$ over 5 min using an Anthos bt2 plate reader. For the determination of AChE activity, $25 \mu \mathrm{L}$ of AChE solution and $25 \mu \mathrm{L}$ of ATCl solution were used instead of the plasma and BTCl solutions. For determination of the inhibition of enzymes, $25 \mu \mathrm{L}$ of an inhibitor solution was added to the test solution instead of the acetonitrile/water (1:1) solution. The uninhibited enzyme solution acted as a positive control during experimentation; negative controls were also run in which enzyme was left out of the mixture in order to account for spontaneous substrate hydrolysis.

\subsection{Monitoring of BuChE inhibition in mouse plasma by compound $18 a$}

Healthy experimentally naïve male CD-1 mice (35-40 g) were obtained from the Bioresources Unit, Trinity College Dublin. The animals were housed in a specific pathogen free (SPF) environment with controlled temperature and humidity in individual cages with isopad bedding (Harlan, UK). The mice had ad libitum access to food and water. A $12 \mathrm{~h}$ light/dark cycle (lights on 7 a.m.-7 p.m. G.M.T.) was in operation. All experiments were performed during the light cycle and carried out in a sound-proof room. All experiments were carried out in accordance with the European (Amendment of Cruelty to Animals Act 1876) Regulations 2002. A single dose of $1 \mathrm{mg} / \mathrm{kg}$ compound 18a, in a volume of $0.1 \mathrm{~mL}$ per $10 \mathrm{~g}$ body weight, was administered to mice ( $n=9$ per group subdivided into groups A, B, C to permit regular sampling) via intraperitoneal (ip) injection into the left lower quadrant of the abdomen using a sterile 21 gauge needle (BD Microlance, UK). Approximately $50 \mu \mathrm{L}$ of submandibular venous blood was collected in $200 \mu \mathrm{L}$ lithium heparinized Microvette capillary tubes (Sarstedt, Germany) and placed on ice. Following blood sampling the mice were returned to their home cages. Prior to terminal blood sampling mice were anaesthetized by administration of ketamine/xylazine ip in a volume of $0.1 \mathrm{~mL} / 10 \mathrm{~g} .{ }^{15}$ Terminal blood samples were obtained via cardiac puncture using a lithium heparinized sterile 25 gauge needle (Sterican, Braun, Germany). Blood samples were centrifuged for $10 \mathrm{~min}$ at $4{ }^{\circ} \mathrm{C}$ at $3000 \mathrm{rpm}$ using a Sorvall centrifuge RT6000B (GMI, USA). The plasma was removed using a Pasteur pipette and pipetted into labelled $1.5 \mathrm{~mL}$ Eppendorfs (Braun, Germany). The Ellman assay was carried out as described.

\section{References and notes}

1. Giacobini, E. Ann. N. Y. Acad. Sci. 2000, 920, 321. PMID: 11193171. DOI: 10.1111/j.1749-6632.2000.tb06942.x.

2. Hoyng, P. F.; van Beek, L. M. Drugs 2000, 59, 411. PMID: 10776828.

3. Keys, P. A.; Blume, R. P. DICP: The Annals of Pharmacotherapy 1991, 25, 1101. PMID: 1803801.

4. Krejčová, G.; Kassa, J. Toxicology 2003, 185, 129. PMID: 12505451. DOI: 10.1016/S0300-483X(02)00599-1.

5. Mesulam, M. M.; Guillozet, A.; Shaw, P.; Levey, A.; Duysen, E. G.; Lockridge, O. Neuroscience 2002, 110, 627. PMID: 11934471. DOI: 10.1016/S0306-4522(01)00613-3.

6. Perry, E. K.; Perry, R. H.; Blessed, G.; Tomlinson, B. E. Neuropathol. Appl. Neurobiol. 1978, 4, 273. PMID: 703927. DOI: 10.1111/j.13652990.1978.tb00545.x.

7. Geula, C.; Mesulam, M. Brain Res. 1989, 498, 185. PMID: 2790472. DOI: 10.1016/0006-8993(89)90419-8.

8. Greig, N. H.; Utsuki, T.; Ingram, D. K.; Wang, Y.; Pepeu, G.; Scali, C.; Yu, Q. S.; Mamczarz, J.; Holloway, H. W.; Giordano, T.; Chen, D.; Furukawa, K.; Sambamurti, K.; Brossi, A.; Lahiri, D. K. Proc. Natl. Acad. Sci. 2005, 102, 17213. PMID: 16275899. DOI: 10.1073/pnas.0508575102.

9. Carolan, C. G.; Dillon, G. P.; Gaynor, J. M.; Reidy, S.; Ryder, S. A.; Khan, D.; Marquez, J. F.; Gilmer, J. F. J. Med. Chem. 2008, $51,6400$. PMID: 18817366. DOI: 10.1021/jm800564y.

10. Khan, D.; Gilmer, J. F.; Carolan, C. G.; Gaynor, J. M.; Ryder, S. A. Chem. Biol. Interact. 2008, 175, 231. PMID: 18606399. DOI: 10.1016/j.cbi.2008.05.024.

11. Ellman, G. L.; Courtney, K. D.; Andres, V., Jr.; Featherstone, R. M. Biochem. Pharmacol. 1961, 7, 88. PMID: 13726518. DOI: 10.1016/0006-2952(61)90145-9.

12. Gaynor, J. M.; Dillon, G. P.; Reidy, S.; Gilmer, J. F. Chem. Biol. Interact. 2005, 157-158, 380. PMID: 16429505. DOI: 10.1016/j.cbi.2005.10.063.

13. Nicolet, Y.; Lockridge, O.; Masson, P.; Fontecilla-Camps, J. C.; Nachon, F. J. Biol. Chem. 2003, 278, 41141. PMID: 12869558. DOI: 10.1074/jbc.M210241200.

14. Sussman, J. L.; Harel, M.; Frolow, F.; Oefner, C.; Goldman, A.; Toker, L.; Silman, I. Science 1991, 253, 872. PMID: 1678899. DOI: 10.1126/science.1678899.

15. Flecknall, P. Laboratory Animal Anaesthesia: An Introduction for Research Workers and Technicians, 2nd ed.; Academic Press: London, 1987. 